\title{
Marine redox variations and nitrogen cycle of the early Cambrian southern margin of the Yangtze Platform, South China: Evidence from nitrogen and organic carbon isotopes
}

\author{
Dan Wang ${ }^{\mathrm{a}, *}$, Ulrich Struck ${ }^{\mathrm{b}}$, Hong-Fei Ling ${ }^{\mathrm{a}}$, Qing-Jun Guo ${ }^{\mathrm{c}}$, Graham A. Shields-Zhou ${ }^{\mathrm{d}, \mathrm{e}}$, \\ Mao-Yan Zhu ${ }^{\mathrm{e}}$, Su-Ping Yao ${ }^{\mathrm{a}}$ \\ a State Key Laboratory for Mineral Deposits Research, School of Earth Sciences and Engineering, Nanjing University, Nanjing 210023, China \\ ${ }^{\mathrm{b}}$ Museum für Naturkunde, Leibniz Institute for Evolution and Biodiversity Science, Berlin 10115, Germany

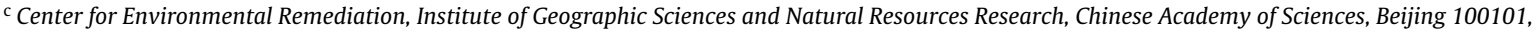 \\ China \\ d Department of Earth Sciences, University College London, Gower Street, London WC1E 6BT, UK \\ e State Key Laboratory of Palaeobiology and Stratigraphy, Nanjing Institute of Geology and Palaeontology, Chinese Academy of Sciences, Nanjing 210008, \\ China
}

\section{A R T I C L E I N F O}

\section{Article history:}

Received 7 November 2014

Received in revised form 11 June 2015

Accepted 23 June 2015

Available online 3 July 2015

\section{Keywords:}

Nitrogen isotopes

Redox variations

$\mathrm{N}$ cycle

Early Cambrian

Yangtze block

\section{A B S T R A C T}

The early Cambrian is a crucial interval, during which the marine environment encountered significant perturbations alongside key biological innovations. The nitrogen isotopic composition of ancient sediments has the potential to record co-variation between the marine ecosystem and environmental conditions. Here we report bulk nitrogen and organic carbon isotopic compositions accompanied by Mo concentration data (a proxy for redox conditions) for a shelf marginal drill core section (Sancha) and a deep basinal outcrop section (Yuanjia) in Hunan province, South China.

For the Cambrian Fortunian Stage, variable $\delta^{15} \mathrm{~N}_{\text {bulk }}$ values ( -4 to $+2 \%$ ) and low $\delta^{13} \mathrm{C}_{\text {org }}$ values ( $-35 \%$ o to $-33 \%$ ) from the Yuanjia section indicate that anoxic waters shoaled into the photic zone, with ammonia assimilation competing with anammox in the basinal area. In the late Cambrian Stage 2 , low $\delta^{15} \mathrm{~N}_{\text {bulk }}$ and $\delta^{13} \mathrm{C}_{\text {org }}$ values, together with high Mo bulk concentrations $\left(\delta^{15} \mathrm{~N}_{\text {bulk }}=-5\right.$ to $0 \%$; $\delta^{13} \mathrm{C}_{\text {org }}=-33.5$ to $-31.0 \%$; > 100 ppm Mo bulk in Sancha section and $\delta^{15} \mathrm{~N}_{\text {bulk }}=\sim 0 \% ; \delta^{13} \mathrm{C}_{\text {org }}=\sim-33 \%$ o $>100 \mathrm{ppm} \mathrm{Mo}_{\text {bulk }}$ in Yuanjia section), reflect intense $\mathrm{N}_{2}$-fixation accompanied by intermittent ammonia assimilation under expanded euxinic condition with shoaling chemocline possibly into the photic zone. In the early Cambrian Stage 3, relatively high $\delta^{15} \mathrm{~N}_{\text {bulk }}$ values, alongside positive $\delta^{13} \mathrm{C}_{\text {org }}$ excursions, at both sections indicate an increasing contribution from ${ }^{15} \mathrm{~N}$-enriched nitrate assimilation and hence more oxic conditions. Shelf margin sediments from the middle and late parts of Cambrian Stage 3 are characterized by low $\delta^{15} \mathrm{~N}_{\text {bulk }}$ values $\left(\sim 0 \%\right.$ ), being lowest in the basinal area ( -3 to $0 \%$ ). In combination with high $\mathrm{Mo}_{\text {bulk }}$ concentration $\left(>100 \mathrm{ppm}\right.$ ) and high $\mathrm{Mo} / \mathrm{TOC}_{\text {bulk }}$ ratios (averaging $\sim 18$ ) in deep basinal sediments, these data suggest that the photic zone became anoxic again, but that sulfidic conditions occurred in the basinal area only. Compared with Stage 2, euxinia was less extensive during this interval, with photosynthetic biomass dominating over chemoautotrophic biomass at both localities.

Based on a combination of $\delta^{15} \mathrm{~N}$ data from this study and published data from studies on contemporaneous sections in Yunnan Province and the Three Gorges area, it is possible to reconstruct the spatial variability and temporal evolution of redox conditions in the various marine environments along the southern margin of the Yangtze platform. The basinal area appears to have been dominated by anoxia and intermittent euxinia in the photic zone during most of the early Cambrian (Fortunian Stage to Stage 3 ) with the exception of more oxic conditions during early Stage 3. On the platform, oxygenated shallow water prevailed with the exception of the notable Cambrian Stage 2 anoxic event. The outer shelf area experienced anoxia from Stage 2 to Stage 3 of the early Cambrian, although of possibly limited areal extent. The high $\mathrm{Mo}_{\text {bulk }}$ concentrations and $\mathrm{Mo} / \mathrm{TOC}_{\text {bulk }}$ ratios suggest that the South China basin was

\footnotetext{
* Corresponding author at: School of Earth Sciences and Engineering, Nanjing University, 163 Xianlin Road, Nanjing 210023, China. Tel.: +86 025 89680885; fax: +8602583686016.

E-mail address: njuwangdan@gmail.com (D. Wang).
} 
well connected with the considerably oxygenated open ocean and that the mean low $\delta^{15} \mathrm{~N}_{\text {bulk }}$ values $\left(\sim+1.6 \%\right.$ o) from the basin may reflect generally lower $\delta^{15} \mathrm{~N}$ composition for seawater nitrate in the early Cambrian compared with modern value.

(C) 2015 Elsevier B.V. All rights reserved.

\section{Introduction}

The early Cambrian is a key interval in the development of the Earth system with major chemical perturbations to the ocean and a significant bio-radiation ('Cambrian Explosion') co-occurring at this time. Revolutionary changes to marine ecosystems during the early Cambrian undoubtedly involved complex mutual interactions and co-evolution with environmental changes. Numerous geochemical data have been obtained to reconstruct changes in the marine environment during that time. Some geochemical studies suggest that ocean basins were well oxygenated by the late Ediacaran (Canfield et al., 2007; Fike et al., 2006; Scott et al., 2008). However, more researchers provide evidence for the persistence of ferruginous and/or intermittently euxinic deep waters into the early Cambrian, particularly over the Yangtze block of South China (Canfield et al., 2008; Goldberg et al., 2007; Li et al., 2010; Och et al., 2013; Poulton and Canfield, 2011; Wille et al., 2008; Xu et al., 2012). The widespread occurrence of oceanic anoxia apparently conflicts with the contemporaneous bio-radiation, necessitating more research into the details of early Cambrian ocean redox conditions.

A 'sandwich'-like model for Precambrian ocean margins has recently been proposed, with mid-depth euxinic waters in between oxic surface waters and ferruginous deep waters (Li et al., 2010, 2012a; Lyons et al., 2012; Poulton and Canfield, 2011; Poulton et al., 2010; Reinhard et al., 2009). Such a 'sandwich'-like redox structure may also have existed during the late Neoproterozoic in South China (Li et al., 2010, 2012a), where it likely persisted into the early Cambrian (Feng et al., 2014; Jin et al., 2014). Mid-depth euxinia over the margins of the Yangtze platform expanded greatly during a worldwide marine transgression in Cambrian Stage 2 ( early Tommotian) and then shrank gradually during the subsequent regression that was accompanied by widespread oxygenation of the shallower realms (Feng et al., 2014; Jin et al., 2014). Such spatial and temporal variations of the marine redox structure have probably played a key role in biological innovation during the contemporaneous Cambrian bio-radiation.

Given that the nitrogen cycle is not only closely related to marine environmental conditions and biological metabolism, but also reflects the ocean redox structure, an increasing number of studies have been conducted on the nitrogen isotope systematics of Ediacaran - early Cambrian marine sediments (Ader et al., 2014; Cremonese et al., 2013, 2014; Kikumoto et al., 2014; Wang et al., 2013). However, these studies mainly focused on the shallow platform realm. In order to better constrain the Early Cambrian N cycle, not only in the shallow platform waters but also in the distant basinal waters, as well as redox conditions along the southern margin of the Yangtze platform, we carried out a comprehensive study of bulk nitrogen and organic carbon isotopes, and Mo concentrations of sedimentary rock samples from a drill core at the shelf margin (Sancha section) and a deep basinal outcrop section (Yuanjia section) in Hunan Province, China (Fig. 1).

\subsection{The marine nitrogen cycle}

Nitrogen is essential for life because this element is an important constituent of amino acids, nucleic acids, pigments such as chlorophyll, and other biomolecules (Canfield et al., 2010; Godfrey and Glass, 2010). The biogeochemical nitrogen cycle is governed by biological functions that are closely coupled to oxygen and carbon cycling. As a consequence, nitrogen isotope signals preserved in organic matter can reflect the redox state of the ocean as well as metabolic processes and pathways. Recently, a growing number of nitrogen isotope studies on marine sediments have demonstrated the potential of $\mathrm{N}$ isotope systematics in reconstructing the environmental and biogeochemical history of the oceans (Robinson et al., 2012; Tesdal et al., 2013).

In the modern ocean, biologically available nitrogen enters the marine system mainly through $\mathrm{N}_{2}$-fixation by aerobic or anaerobic autotrophs such as cyanobacteria with a negligible isotopic fractionation (Sigman et al., 2009). After the death of organisms, organic- $\mathrm{N}$ is converted to ammonium $\left(\mathrm{NH}_{4}{ }^{+}\right)$through ammonification with little fractionation $\left(\varepsilon=\delta^{15} \mathrm{~N}_{\text {reactant }}-\delta^{15} \mathrm{~N}_{\text {product }}<3 \%\right.$ o) (Prokopenko et al., 2006; Sigman et al., 2009). This ammonium is then rapidly oxidized to nitrite $\left(\mathrm{NO}_{2}{ }^{-}\right)$and subsequently to nitrate $\left(\mathrm{NO}_{3}{ }^{-}\right)$through nitrification with negligible fractionation under modern oxic conditions or with a significant fractionation under oxygen-deficient conditions (Sigman et al., 2009; Wang et al., 2013). The removal of fixed- $\mathrm{N}$ from the marine system takes place via denitrification and anaerobic ammonium oxidation (or anammox) in anoxic environments, if not retained in the sedimentary pile. During denitrification, oxidized $\mathrm{N}$ species $\left(\mathrm{NO}_{3}{ }^{-}\right.$and $\left.\mathrm{NO}_{2}{ }^{-}\right)$ are reduced to gaseous forms of $\mathrm{N}$ such as nitrous oxide $\left(\mathrm{N}_{2} \mathrm{O}\right)$ or $\mathrm{N}_{2}$ with substantial isotopic fractionation (c. $20 \%$ o to $30 \%$ ) in the water column, but with negligible fractionation in the sediments (Sigman et al., 2009). The anammox process is conducted by strictly anaerobic chemoautotrophic bacteria with ammonium $\left(\mathrm{NH}_{4}{ }^{+}\right.$) being oxidized to $\mathrm{N}_{2}$ by nitrite $\left(\mathrm{NO}_{2}{ }^{-}\right)$(Kuypers et al., 2003); isotopic fractionation during this process remains unclear but has been inferred to be $\sim 25 \%$ (Prokopenko et al., 2006). During both water-column denitrification and anammox processes, ${ }^{14} \mathrm{NO}_{3}{ }^{-}$is preferentially used and so the heavier isotope ${ }^{15} \mathrm{~N}$ will become relatively enriched in the nitrate pool (Sigman et al., 2009).

Today phototrophic organisms are able to utilize various forms of dissolved nitrogen species such as dinitrogen, nitrate, ammonia and urea to synthetize organic matter, which is then transported to the sediments and preserved through geological time (Sigman et al., 2009; Waser et al., 1998). However, organic particles are mostly produced in the euphotic zone, and they usually go through biotic alterations such as microbial digestion or deamination during sinking and deposition (Robinson et al., 2012). In modern oceans, suspended organic particles in surface waters have the lowest $\delta^{15} \mathrm{~N}$ due to $\mathrm{N}_{2}$ fixation or assimilation of low- $\delta^{15} \mathrm{~N}$ ammonium released by heterotrophic organisms (ammonium recycling), but their $\delta^{15} \mathrm{~N}$ values increase below the euphotic zone (Altabet, 1988; Sigman et al., 2009). Particulate nitrogen, which is relatively enriched in ${ }^{15} \mathrm{~N}$, is preferentially exported as sinking particles. The $\delta^{15} \mathrm{~N}$ values of these particles do not change with depth in regions of high sediment accumulation such as continental margins, but show a slightly decreasing trend in regions of low organic $\mathrm{N}$ depositional flux (Altabet et al., 1991; Sigman et al., 2009).

It has been suggested that $\delta^{15} \mathrm{~N}$ alteration occurs mainly at the seafloor, and that there may be various changes in the $\delta^{15} \mathrm{~N}$ of bulk sediments such as increases or decreases during early burial in low-productivity regions, depending on oxic or anoxic conditions, respectively (Lehmann et al., 2003; Robinson et al., 2012). Diagenetic alteration under oxic conditions usually increases the $\delta^{15} \mathrm{~N}$ composition of organic matter (Gaye et al., 2009; Lehmann et al., 2002; Möbius et al., 2011; Nakanishi and Minagawa, 2003). This is 


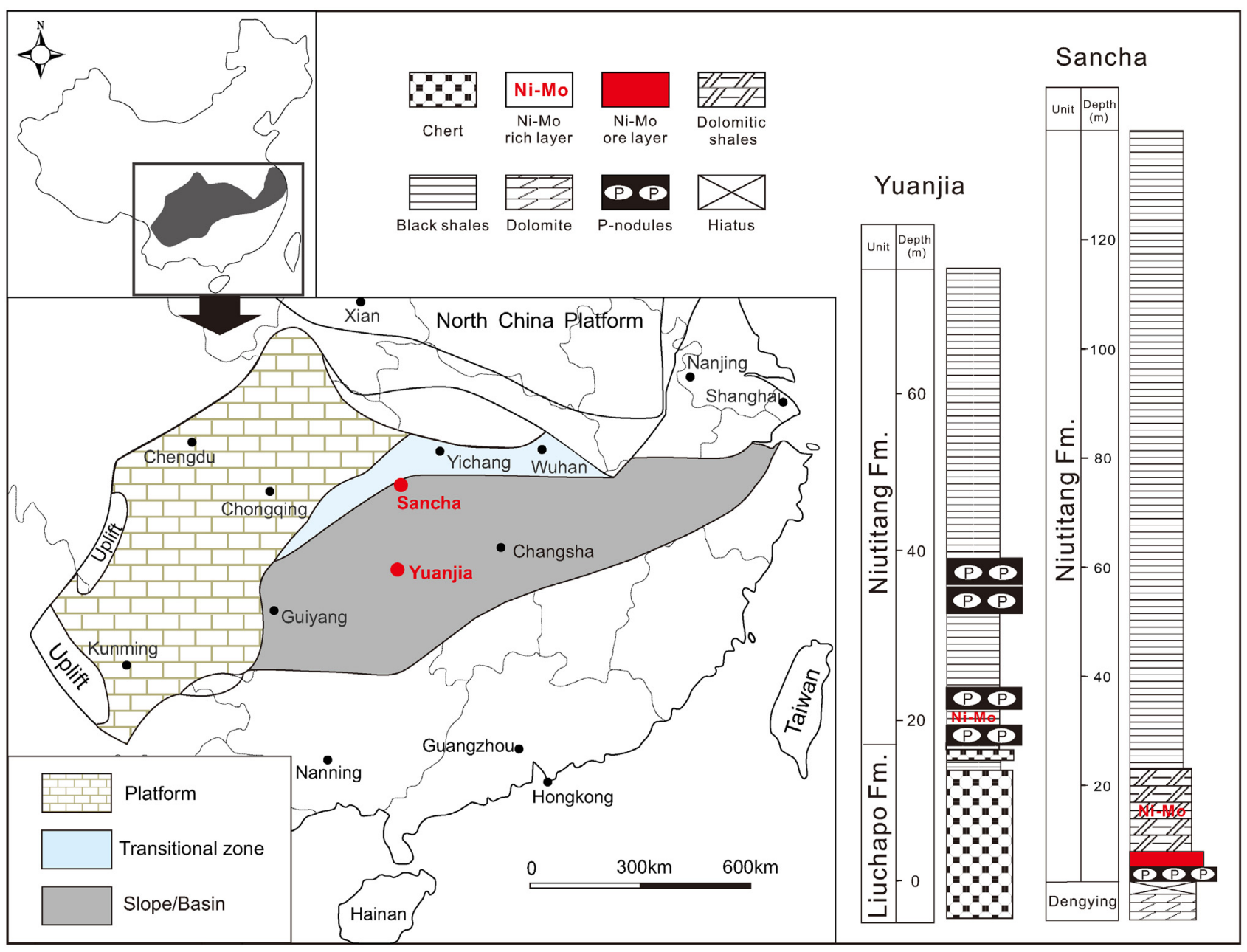

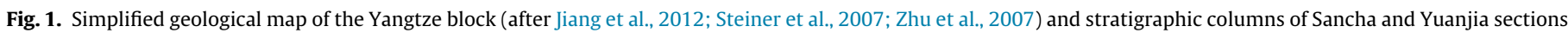
(after Li et al., 2012b and Guo et al., 2013).

because amino acids are much more easily degraded and therefore release more ${ }^{14} \mathrm{~N}$ under oxic than anoxic conditions (Nguyen and Harvey, 1997). However, $\mathrm{NH}_{4}{ }^{+}$generated beneath the seafloor can be captured by clay minerals, in which case $\delta^{15} \mathrm{~N}_{\text {bulk }}$ values may show little or no change (Freudenthal et al., 2001).

In the modern oxygenated oceans, the global mean $\delta^{15} \mathrm{~N}$ value of nitrate is $\sim+5 \%$ o (Sigman et al., 2009), and the average $\delta^{15} \mathrm{~N}$ value in sediments is $\sim+7 \%$, which is close to the expected value following complete assimilation of seawater nitrate and minor modification at the seafloor (Pinti and Hashizume, 2011). By contrast, in some regions near zones of water column anoxia with high water-column denitrification and/or anammox rates and complete nitrate assimilation, the $\delta^{15} \mathrm{~N}$ values of seafloor sediments may be higher (Tesdal et al., 2013). In some modern stratified basins such as the Black Sea, where the $\mathrm{O}_{2} / \mathrm{H}_{2} \mathrm{~S}$ interface exists in the water column instead of in the sediment column, green or purple sulfur bacteria (GSB and $\mathrm{PSB}$ ) that live principally near the chemocline in the presence of free $\mathrm{H}_{2} \mathrm{~S}$ in the photic zone (Ohkouchi et al., 2005) can either participate in $\mathrm{N}_{2}$-fixation or assimilate ammonia and/or nitrite with a large and variable fractionation depending on the seawater ammonia concentration (Ohkouchi et al., 2005; Pennock et al., 1996), producing very low $\delta^{15} \mathrm{~N}$ values. In these anoxic environments, microbial degradation is suggested to retain the initial $\delta^{15} \mathrm{~N}$ value or only slightly decrease the $\delta^{15} \mathrm{~N}$ value (Altabet et al., 1999; Higgins et al., 2010; Junium and Arthur, 2007; Möbius et al., 2010). Therefore, $\delta^{15} \mathrm{~N}$ values of sediments can directly reflect both the nitrogen biogeochemical cycle and the redox conditions in the marine environment. However, an evaluation is needed to determine whether or not the original $\delta^{15} \mathrm{~N}$ values of sediments have been significantly modified during diagenesis, before they can be used as a biogeochemical tracer.

\subsection{Molybdenum geochemistry}

The trace element molybdenum, preserved in black shales, can be a useful redox proxy of the ancient ocean (Algeo and Maynard, 2004; Dahl et al., 2011; Scott et al., 2008; Scott and Lyons, 2012; Tribovillard et al., 2006). In the modern oxygenated ocean, Mo is the most abundant transition metal $(\sim 105 \mathrm{nM})$ (Collier, 1985; Lyons et al., 2009) and exists primarily as molybdate $\left(\mathrm{MoO}_{4}{ }^{2-}\right)$, with a residence time of $\sim 0.8 \mathrm{Myr}$ (Emerson and Huested, 1991; Morford and Emerson, 1999). The major source of Mo to the ocean is oxidative weathering of crustal sulfides and black shales (Bertine and Turekian, 1973). The largest modern oceanic sink for Mo is co-precipitation and adsorption with Mn-oxyhydroxides in oxic environments (Barling et al., 2001; McManus et al., 2006; Siebert et al., 2003). However, the behavior of Mo depends strongly on redox conditions. Under anoxic and non-sulphidic (ferruginous) conditions, dissolved Mo can be transported to the sediments via absorption to Fe (oxyhydr)oxides as has been observed in the modern ferruginous Matano Lake, Indonesia (Crowe et al., 2008a; Goldberg et al., 2009). In anoxic environments with minor amounts of dissolved sulfide, molybdate transported from the oxic environment is converted to a series of particle-reactive thiomolybdate 
$\left(\mathrm{MoO}_{x} \mathrm{~S}_{4-x}{ }^{2-}\right)$ species (Helz et al., 1996). Furthermore, in euxinic seawater, in which aqueous hydrogen sulfide $\left(\mathrm{H}_{2} \mathrm{~S}\right)$ exceeds a threshold concentration of about $11 \mu \mathrm{mol}$, tetrathiomolybdate $\left(\mathrm{MoS}_{4}{ }^{2-}\right)$ forms and is rapidly scavenged by pyrite and organic matter, resulting in near-quantitative removal of Mo (Algeo and Lyons, 2006; Erickson and Helz, 2000; Helz et al., 1996, 2011; Huerta-Diaz and Morse, 1992; Tribovillard et al., 2004; Vorlicek and Helz, 2002; Vorlicek et al., 2004). This leads to significant Mo enrichment in the sediments as long as concentrations remain high in ambient seawater. Previous studies have concluded that minor Mo enrichments in black shales (between crustal average $2 \mathrm{ppm}$ to $25 \mathrm{ppm}$ ) normally imply non-euxinic conditions, while large Mo enrichments (>100 ppm) represent permanently euxinic conditions in the depositional environment, and imply a good connection to the oxic open ocean (Algeo and Lyons, 2006; Scott and Lyons, 2012). Intermediate Mo enrichments (25-100 ppm) may reflect either intermittent euxinia or Mo depletion in the water column (Algeo and Lyons, 2006; Scott and Lyons, 2012).

Mo concentrations and TOC contents exhibit co-variation in modern euxinic marine sediments as well as in many ancient black shales (Algeo and Lyons, 2006; Algeo and Maynard, 2004; Holland, 1984; Robl and Barron, 1988). It has been demonstrated that sedimentary Mo/TOC ratios can be a useful paleohydrographic proxy to assess the degree of watermass restriction, but only under anoxic conditions (Algeo and Lyons, 2006; Algeo and Rowe, 2012). In sulfidic silled basins, aqueous Mo concentrations can be lowered as a result of sedimentary Mo uptake without adequate resupply through deep water renewal (Algeo and Lyons, 2006; Algeo and Rowe, 2012). As a result, sedimentary Mo concentrations and $\mathrm{Mo} / \mathrm{TOC}$ ratios decrease as the redox conditions become increasingly sulfidic in silled basins, and it has been suggested that modern sedimentary Mo/TOC ratios with values of $>35, \sim 15-35$, and $<15$ indicate weak, moderate, and strong restriction, respectively (Algeo and Lyons, 2006; Algeo and Rowe, 2012).

By analyzing the nitrogen isotope compositions and Mo concentrations of bulk sedimentary samples, we hope to be able to reveal primary changes in nutrient cycling/sources to the ancient ocean, and to identify the dominant metabolic process (nitrogen fixation, or nitrification, or denitrification/anammox) involved in nitrogen cycling. Based on these data and results from previous studies of the neighboring, shallow marine environment, we further discuss changes in productivity, ecosystem evolution and chemical/redox stratification of the basin along the southern margin of the Yangtze platform during the early Cambrian.

\section{Geological setting}

Paleogeographic reconstruction shows that the late Ediacaran-early Cambrian succession overlying the Yangtze block of South China was deposited in various paleoenvironmental settings from large platformal areas with a transitional zone interpreted as outer shelf, into slope and then deeper more basinal areas (Jiang et al., 2012; Steiner et al., 2007; Zhu et al., 2007). The shelf regions of the Yangtze block were subaerially exposed and partially eroded during the earliest Cambrian, but a transgression during Cambrian Stage 2 ( early Tommotian) submerged the shelf margins and led to homogeneous deposition of fine-grained, frequently organic-rich sediments across the entire Yangtze block (Jiang et al., 2012; Steiner et al., 2007; Zhu et al., 2003). These 'black shales' are suggested to have been deposited under widespread anoxic, or even euxinic conditions based on numerous lines of geochemical evidence (Canfield et al., 2008; Goldberg et al., 2005, 2007; Guo et al., 2007a; Kimura and Watanabe, 2001; Lehmann et al., 2007; Och et al., 2013; Wang et al., 2012a; Wille et al., 2008; Xu et al., 2012). Presumably, because of the rapidity of this sea level rise, lower Cambrian units across much of South China are condensed with only a few centimeters thickness in the deeper water realms (Goldberg et al., 2007; Schütter, 1998; Steiner et al., 2001, 2007). Related to this condensation, a polymetallic enrichment layer occurs sporadically in the lower portion of this transgressive black shale along a NE-striking $1600 \mathrm{~km}$ belt, which can be used as a correlation marker (Jiang et al., 2012; Och et al., 2013; Zhu et al., 2003), but mineable ore layer is usually less than half meters in thickness and exposed only within Guizhou and Hunan provinces (Jiang et al., 2006, 2007). The deposit formed under sulfidic depositional conditions although the origin of the metal enrichment has proven controversial (Jiang et al., 2006; Lehmann et al., 2007; Steiner et al., 2007).

Our two studied sections are both located in Hunan Province where the sedimentary facies dramatically changes from platform margin to slope and deep basinal facies (Vernhet, 2007). Drill core samples were obtained from the Sancha section in Zhangjiajie. The Sancha section is located at shelf margin area and consists of uppermost Dengying and Niutitang formations with a sedimentary hiatus between them. The uppermost Dengying Formation consists mainly of massive dolomite, while the overlying Niutitang Formation comprises black shales and siltstone with phosphatic nodules and a polymetallic rich layer at the base (Fig. 1). $\mathrm{Pb}-\mathrm{Pb}$ ages of $521 \pm 54$ Ma for sulfide ores from Sancha section outcrops in Hunan and of $531 \pm 24$ Ma for the underlying black shales at Zunyi, Guizhou have been obtained (Jiang et al., 2006). These ages are consistent with the Re-Os isochron age of $521 \pm 5 \mathrm{Ma}(n=14)$ for the sulfide ore layer at the base of the Niutitang Formation sampled at three mine sites at the Sancha, Dazhuliushui and Maluhe sections (Xu et al., 2011) and also with the U-Pb age of $532 \pm 0.7 \mathrm{Ma}$ for zircons from a volcanic ash bed beneath the Ni-Mo sulfide marker layer in the lowermost Niutitang Formation in Guizhou province (Jiang et al., 2009).

The Yuanjia section in Zhongfang County which is a basinal section (Jiang et al., 2011) consists of the upper part of the Liuchapo Formation and the overlying Niutitang Formation. The Liuchapo Formation is mainly composed of black cherts with phosphatic siliceous interlayers. The Niutitang Formation comprises mainly black shales with a phosphatic nodule layer and a polymetallic rich layer at the base and another phosphate nodule layer at a horizon $33-40 \mathrm{~m}$ from the base of the section (Fig. 1). The Precambrian-Cambrian boundary has been suggested to be placed within the upper Liuchapo Formation where there occurs a negative $\delta^{13} C_{\text {org }}$ excursion that could be correlated with the negative $\delta^{13} C_{\text {carb }}$ excursion in the Daibu Member of the Zhujiaqing Formation at Xiaotan section (Guo et al., 2013; Li et al., 2013a; Zhou et al. 1997).

High organic $\mathrm{H} / \mathrm{C}$ ratios $(0.3-1.8)$ of the Liuchapo and Xiaoyanxi (equivalent to the Niutitang Formation) formations at the Yanwutan-Lijiatuo section, which is about $75 \mathrm{~km}$ away from Sancha section and only $4 \mathrm{~km}$ away from Yuanjia section in Hunan Province (Guo et al., 2007b), suggest that the studied area did not experienced greenschist facies metamorphism (Hayes et al., 1983). Observations on the petrography of sedimentary rocks at the studied sections and on the regional geology also show that the Ediacaran and early Cambrian strata in this region preserve original structures of the shales and mudstones, suggesting little metamorphism occurred to the strata.

\section{Material and methods}

The Sancha drill-core samples guarantee minimum secondary alteration due to surface weathering. For the Yuanjia outcrop section, only fresh samples were selected for chemical treatment and isotopic analyses. All selected samples were cut into pieces about 
$3-5 \mathrm{~cm}$ in diameter avoiding calcite or siliceous veining and ground into a homogeneous powder. Ground samples were oven-dried at a temperature of $40^{\circ} \mathrm{C}$, in preparation for carbon and nitrogen isotope analyses. Isotopic ratios for nitrogen and organic carbon were measured in the laboratories of the "Museum für Naturkunde" in Berlin using a Thermo Finnigan Elemental Delta V Mass Spectrometer coupled with a Thermo 1112 Flash Elemental Analyser via a Thermo ConfloIII Interface. Replicates of $\delta^{13} C_{\text {org }}$ and $\delta^{15} \mathrm{~N}_{\text {bulk }}$ sample analyses exhibited a standard deviation of less than $\pm 0.3 \%$.

For carbon isotope analysis, about $20-30 \mathrm{mg}$ of ground sample were weighed and digested in $2 \mathrm{~mol} / \mathrm{L}$ hydrochloric acid $(\mathrm{HCl})$ overnight to completely remove carbonate. Residues were washed with distilled water to remove chlorides and dried at $40^{\circ} \mathrm{C}$ overnight. The decalcified sample powder was then wrapped into tin capsules for organic carbon isotope and total organic carbon $\left(\mathrm{TOC}_{\text {decarb }}\right)$ measurements. Carbon isotope values $\left(\delta^{13} \mathrm{C}_{\mathrm{org}}\right)$ are reported in per mil relative to the international V-PDB standard value. Total nitrogen and organic carbon contents in decalcified samples $\left(\mathrm{TN}_{\text {decarb }}\right.$ and $\left.\mathrm{TOC}_{\text {decarb }}\right)$ were measured at the Center of Modern Analysis Nanjing University, using Elementar Vario MICRO.

According to the organic matter content, approximately 30-150 mg of bulk material was weighed into tin capsules for nitrogen isotope and total nitrogen content $\left(\mathrm{TN}_{\text {bulk }}\right)$ measurements and a carbon-absorbing trap was used in the EA to avoid interferences during the nitrogen isotope analysis due to high carbon contents. Nitrogen isotope delta values $\left(\delta^{15} \mathrm{~N}_{\text {bulk }}\right.$ ) are reported relative to air and $\delta^{15} \mathrm{~N}_{\text {bulk }}$ and $\mathrm{TN}_{\text {bulk }}$ data are calculated using a Peptone house-standard whose value is $\delta^{15} \mathrm{~N}_{\text {bulk }}=+7.6 \%$, $\mathrm{TN}=12.1 \%$. Samples with total nitrogen content $\left(\mathrm{TN}_{\text {bulk }}\right)$ higher than $0.012 \mathrm{mg}$ are considered to yield reasonable $\delta^{15} \mathrm{~N}_{\text {bulk }}$ results. The reliability of nitrogen isotope analytical performance has been proven previously in extensive 'Round Robin' comparative testing (Bahlmann et al., 2010).

Trace element contents were measured at two laboratories: at the State Key Laboratory for Mineral Deposits Research, Nanjing University using a Bruker Aurora M90 ICP-MS, and at the laboratory of the Institute of Geographic Sciences and Natural Resources Research, using a PE Elan DRC-e ICP-MS. Bulk samples were leached with $2 \mathrm{~mol} / \mathrm{L} \mathrm{HCl}$ in order to remove carbonate and phosphate, after which the remains were fully dissolved in high pressure Teflon bombs using a conc. $\mathrm{HF}+$ conc. $\mathrm{HNO}_{3}$ mixture with a volume ratio of $1: 3$. After evaporation, samples were re-dissolved in $3 \% \mathrm{HNO}_{3}$ for analysis. Analytical uncertainties for most elements were typically lower than $5 \%$.

\section{Results}

The results for bulk nitrogen $\left(\delta^{15} \mathrm{~N}_{\text {bulk }}\right)$ and organic carbon $\left(\delta^{13} C_{o r g}\right)$ isotopes, total organic carbon contents in bulk and decarbonated samples ( $\mathrm{TOC}_{\text {bulk }}$ and $\mathrm{TOC}_{\text {decarb }}$ ), total nitrogen contents in bulk and decarbonated samples $\left(\mathrm{TN}_{\text {bulk }}\right.$ and $\left.\mathrm{TN}_{\text {decarb }}\right)$ and Mo concentrations in bulk samples $\left(\mathrm{Mo}_{\text {bulk }}\right)$ from the Sancha and Yuanjia sections are presented in Tables 1 and 2, together with $\mathrm{C} / \mathrm{N}_{\text {decarb }}$ ratios (calculated from the measured $\mathrm{TOC}_{\text {decarb }}$ and $\mathrm{TN}_{\text {decarb }}$ contents on an atomic basis) and $\mathrm{Mo} / \mathrm{TOC}_{\text {bulk }}$ ratios (calculated directly from the measured $\mathrm{Mo}_{\text {bulk }}$ concentration and $\mathrm{TOC}_{\text {bulk }}$ data, ppm/\%). Depth profiles for $\delta^{15} \mathrm{~N}_{\text {bulk }}, \delta^{13} \mathrm{C}_{\mathrm{org}}$, $\mathrm{TOC}_{\mathrm{bulk}}, \mathrm{TN}_{\mathrm{bulk}}$, $\mathrm{Mo}_{\text {bulk }}$ concentrations and $\mathrm{Mo} / \mathrm{TOC}_{\text {bulk }}$ for both sections are shown in Fig. 2.

\subsection{Sancha section}

For the phosphatic nodule and polymetallic rich unit in the lower Niutitang Formation $(0-20 \mathrm{~m})$, the $\delta^{13} \mathrm{C}_{\text {org }}$ profile fluctuates between $-33.5 \%$ and $-31.0 \%$, and exhibits a small negative shift.
The $\mathrm{TOC}_{\text {bulk }}$ contents are high, ranging from $1.1 \%$ to $19.0 \%$ with an average value of $9.4 \%$. The $\delta^{15} \mathrm{~N}_{\text {bulk }}$ profile smoothly decreases from $+1.1 \%$ o to $-1.0 \%$, with the exception of a sharp negative shift to the lowest value $-4.7 \%$. $\mathrm{TN}_{\text {bulk }}$ contents lie between $0.025 \%$ and $0.134 \%$, averaging $0.092 \%$. $\mathrm{Mo}_{\text {bulk }}$ concentrations are high, ranging from $30 \mathrm{ppm}$ to $1180 \mathrm{ppm}$, averaging $166 \mathrm{ppm}$. Correspondingly, $\mathrm{Mo} / \mathrm{TOC}_{\text {bulk }}$ ratios are relatively high, averaging 27.6 (Fig. 2a).

For the black shales in the middle part of the Niutitang Formation $(20-80 \mathrm{~m}), \delta^{13} \mathrm{C}_{\text {org }}$ values firstly increase to a high value of $-29.3 \%$, then decrease back to a low value of $-31.2 \%$, exhibiting a positive excursion in this interval. TOC $_{\text {bulk }}$ contents decrease to $0.7-3.1 \%$, averaging $1.8 \% . \delta^{15} \mathrm{~N}_{\text {bulk }}$ values are relatively high, fluctuating between $+0.3 \%$ ond $+3.1 \%$, accompanied by relatively stable $\mathrm{TN}_{\text {bulk }}$ contents $(0.042 \%$ to $0.132 \%$, with an average of $0.101 \%$ ). Similarly, $\mathrm{Mo}_{\text {bulk }}$ concentrations decrease to 7-46 ppm with an average value of $23 \mathrm{ppm}$, while $\mathrm{Mo} / \mathrm{TOC}_{\text {bulk }}$ ratios range from 7.8 to 20.5 , averaging 13.4 (Fig. 2a).

For the black shales in the upper part of the Niutitang Formation $(80-140 \mathrm{~m}), \delta^{13} \mathrm{C}_{\text {org }}$ values remain constant between $-30.6 \%$ 。 and $-30.2 \%$. TOC $_{\text {bulk }}$ contents in this part are low, averaging $0.3 \%$. The $\delta{ }^{15} \mathrm{~N}_{\text {bulk }}$ curve continuously decreases to near zero, and $\mathrm{TN}_{\text {bulk }}$ contents do not show any apparent change (averaging $0.073 \%$ ). $\mathrm{Mo}_{\text {bulk }}$ concentrations are low, averaging $3 \mathrm{ppm}$, while Mo/TOC bulk ratios average 7.9 (Fig. 2a).

\subsection{Yuanjia section}

In the upper part of the Liuchapo Formation (0-18 $\mathrm{m}), \delta^{13} \mathrm{C}_{\text {org }}$ values are relatively low and exhibit a negative excursion, firstly decreasing from $-33.9 \%$ o to $-34.8 \%$, and then increasing back to $-32.9 \%$ in the uppermost Liuchapo Formation. TOC $_{\text {bulk }}$ contents range from $1.0 \%$ to $6.9 \%$, averaging $2.9 \% . \delta^{15} \mathrm{~N}_{\text {bulk }}$ values mainly fluctuate between $-4.3 \%$ and $+1.4 \%$. $\mathrm{TN}_{\text {bulk }}$ contents are relatively low, ranging between $0.013 \%$ and $0.047 \%$ with an average value of $0.024 \%$. Mo bulk concentrations are between $2.20 \mathrm{ppm}$ and $30.2 \mathrm{ppm}$ with an average value of $11.7 \mathrm{ppm}$. Correspondingly, Mo/TOC ratios are characterized by an average value of 4.1 (Fig. 2b).

For the phosphatic nodule and polymetallic rich unit in the lower Niutitang Formation (18-22 m), $\delta^{15} \mathrm{~N}_{\text {bulk }}$ values fluctuate around zero and $\delta^{13} \mathrm{C}_{\text {org }}$ values are relatively constant around $-32.5 \%$. TOC $_{\text {bulk }}$ contents sharply increase above $10 \%$ while $\mathrm{TN}_{\text {bulk }}$ contents gradually increase from $0.024 \%$ to $0.117 \%$. $\mathrm{Mo}_{\text {bulk }}$ concentrations obtain their highest level here at $271 \mathrm{ppm}$ with a highest Mo/TOC bulk ratio of 13.9 (Fig. 2b).

For the black shales with phosphate nodules layer in the middle part of the Niutitang Formation $(22-40 \mathrm{~m}), \delta^{13} \mathrm{C}_{\text {org }}$ values increase to $-30.6 \%$, and then decrease back to $-33.6 \%$ at the top of the second phosphate nodule layer. TOC $_{\text {bulk }}$ contents are high, ranging from $2.1 \%$ to $19.0 \%$ with an average value of $12.2 \%$. However, TOC $_{\text {bulk }}$ contents of three samples (Yuj-563, Yuj-565 and Yuj-568) are abnormally low. Although this might be attributed to the degradation of organic matter, the $\delta^{13} C_{\text {org }}$ positive excursion during this interval remains unaffected. $\delta^{15} \mathrm{~N}_{\text {bulk }}$ values exhibit a positive excursion $\left(-1.63 \%\right.$ o to $+2.16 \%$ ), accompanied by increasing $\mathrm{TN}_{\text {bulk }}$ contents (0.024-0.249\%, averaging $0.136 \%$ ). Mo bulk concentrations range between $2.21 \mathrm{ppm}$ and $100 \mathrm{ppm}$, averaging $44.3 \mathrm{ppm}$. The average value of $\mathrm{Mo} / \mathrm{TOC}_{\text {bulk }}$ ratios is 3.5 (Fig. $2 \mathrm{~b}$ ).

For the black shales in the upper part of the Niutitang Formation (40-71 $\mathrm{m}$ ), the $\delta^{13} \mathrm{C}_{\text {org }}$ curve keeps increasing from $-33.1 \%$ to $-31.7 \%$, while $\mathrm{TOC}_{\text {bulk }}$ contents are consistently high, averaging $12.1 \%$. $\delta^{15} \mathrm{~N}_{\text {bulk }}$ values decrease smoothly from $+1.8 \%$ o to $-3.0 \%$. Meanwhile, the $\mathrm{TN}_{\text {bulk }}$ contents jaggedly decrease from approximately $0.25 \%$ to $0.05 \%$. Notably, $\mathrm{Mo}_{\text {bulk }}$ concentrations dramatically increase to over hundreds of ppm, averaging $229 \mathrm{ppm}$. 
Table 1

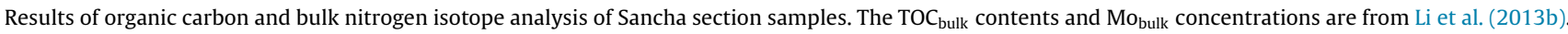

\begin{tabular}{|c|c|c|c|c|c|c|c|c|c|c|c|}
\hline \multirow[t]{2}{*}{ Sample } & \multirow[t]{2}{*}{ Lithology } & \multirow{2}{*}{$\begin{array}{l}\text { Depth } \\
(\mathrm{m})\end{array}$} & \multirow{2}{*}{$\begin{array}{l}\delta^{13} C_{\text {org }} \\
(\%)\end{array}$} & \multicolumn{2}{|l|}{ TOC (\%) } & \multirow{2}{*}{$\begin{array}{l}\delta^{15} \mathrm{~N}_{\text {bulk }} \\
(\% \circ)\end{array}$} & \multicolumn{2}{|l|}{$\mathrm{TN}(\%)$} & \multirow{2}{*}{$\begin{array}{l}\mathrm{C} / \mathrm{N} \text { (atom) } \\
\text { decarb }\end{array}$} & \multirow{2}{*}{$\begin{array}{l}\mathrm{Mo}_{\text {bulk }} \\
\text { (ppm) }\end{array}$} & \multirow{2}{*}{$\begin{array}{l}\text { Mo/TOC bulk } \\
(\mathrm{ppm} / \%)\end{array}$} \\
\hline & & & & decarb & bulk & & decarb & bulk & & & \\
\hline \multicolumn{12}{|c|}{ Niutitang Formation } \\
\hline SC-001 & P-nodules layer & 0 & -31 & 9.3 & 1.1 & & 0.037 & & 293.9 & 238 & 217.9 \\
\hline SC-003 & P-nodules layer & 1.7 & -31.9 & 4.4 & 1.2 & 0.4 & 0.029 & 0.025 & 177.8 & 30 & 25.7 \\
\hline SC-004 & P-nodules layer & 2.4 & -31.1 & 19.4 & 19.0 & -0.1 & 0.240 & 0.085 & 94.5 & 67 & 3.5 \\
\hline SC-005 & P-nodules layer & 2.9 & -33.5 & 25.6 & 17.9 & 1.1 & 0.344 & 0.134 & 86.7 & 32 & 1.8 \\
\hline SC-009 & Ni-Mo layer & 4.2 & -32.3 & 19.1 & 16.2 & -0.5 & 0.188 & 0.102 & 118.3 & 220 & 13.6 \\
\hline SC-011 & Ni-Mo layer & 5.7 & -32.4 & 17.4 & 15.1 & -0.1 & 0.181 & 0.105 & 111.8 & 1180 & 77.9 \\
\hline SC-013 & Dolomitic black shales & 7.7 & -31.8 & 15.1 & 14.1 & -0.2 & 0.168 & 0.099 & 105.0 & 120 & 8.5 \\
\hline SC-015 & Dolomitic black shales & 8.7 & -31.9 & 15.3 & 12.0 & -0.5 & 0.151 & 0.096 & 118.3 & 142 & 11.8 \\
\hline SC-016 & Dolomitic black shales & 9.1 & -32 & 8.8 & 8.3 & -0.5 & 0.154 & 0.094 & 66.9 & 129 & 15.5 \\
\hline SC-017 & Dolomitic black shales & 9.7 & -31.8 & 3.6 & 1.8 & -0.9 & 0.043 & 0.034 & 97.1 & 31 & 17.3 \\
\hline SC-019 & Dolomitic black shales & 10.7 & -31.9 & 9.7 & 8.9 & -0.6 & 0.144 & 0.088 & 78.5 & 119 & 13.4 \\
\hline SC-021 & Dolomitic black shales & 11.9 & -31.8 & 7.0 & 6.6 & -0.5 & 0.170 & 0.104 & 48.1 & 202 & 30.8 \\
\hline SC-023 & Dolomitic black shales & 12.9 & -31.8 & 8.1 & 7.7 & -4.7 & 0.123 & 0.118 & 76.6 & 99 & 12.9 \\
\hline SC-026 & Dolomitic black shales & 14.6 & -32.4 & 5.2 & 4.8 & -1 & 0.100 & 0.061 & 60.8 & 88 & 18.2 \\
\hline SC-028 & Dolomitic black shales & 15.6 & -31.5 & 7.2 & 4.6 & -0.8 & 0.134 & 0.060 & 62.7 & 96 & 20.6 \\
\hline SC-030 & Dolomitic black shales & 17.2 & -31.6 & 13.4 & 12.6 & 0 & 0.155 & 0.091 & 101.2 & 205 & 16.3 \\
\hline SC-031 & Dolomitic black shales & 18.2 & -31.5 & 8.9 & 7.5 & 0.5 & 0.143 & 0.110 & 72.2 & 42 & 5.6 \\
\hline SC-033 & Dolomitic black shales & 19.8 & -32.9 & 11.4 & 10.1 & 0.8 & 0.169 & 0.123 & 78.7 & 63 & 6.3 \\
\hline SC-037 & Dolomitic black shales & 22.9 & -31.1 & 9.7 & 8.9 & 0.7 & 0.167 & 0.125 & 67.7 & 60 & 6.8 \\
\hline SC-039 & Black shales & 24.5 & -30.4 & 2.4 & 2.2 & 0.8 & 0.124 & 0.108 & 22.2 & 46 & 20.5 \\
\hline SC-042 & Black shales & 27 & -30.1 & 2.3 & 2.1 & 1 & 0.107 & 0.105 & 24.9 & 32 & 14.9 \\
\hline SC-047 & Black shales & 31.1 & -31.3 & 2.1 & 2.0 & 2.5 & 0.154 & 0.132 & 15.5 & 32 & 16.4 \\
\hline SC-050 & Black shales & 34.1 & -30.1 & 2.1 & 2.0 & 2.2 & 0.132 & 0.108 & 18.2 & 30 & 15.0 \\
\hline SC-058 & Black shales & 39.6 & -29.8 & 2.8 & 2.7 & 1.4 & 0.127 & 0.111 & 26.1 & 21 & 7.8 \\
\hline SC-064 & Black shales & 44.5 & -29.6 & 2.4 & 2.3 & 2 & 0.146 & 0.114 & 18.9 & 19 & 8.3 \\
\hline SC-069 & Black shales & 49.4 & -30 & 3.2 & 3.1 & 0.8 & 0.133 & 0.092 & 28.2 & 43 & 14.1 \\
\hline SC-070 & Black shales & 50.9 & -29.3 & & & 0.7 & 0.089 & 0.094 & 0.0 & 12 & \\
\hline SC-073 & Black shales & 53.6 & -29.9 & 2.2 & 1.9 & 1.8 & 0.124 & 0.101 & 20.7 & 22 & 11.3 \\
\hline SC-076 & Black shales & 56.7 & -30.2 & 1.9 & 0.8 & 0.3 & 0.121 & 0.042 & 18.1 & 7 & 8.6 \\
\hline SC-081 & Black shales & 62.6 & -29.9 & 0.9 & 0.8 & 2 & 0.127 & 0.098 & 7.8 & 13 & 16.0 \\
\hline SC-088 & Black shales & 74.3 & -30.3 & 0.9 & 0.8 & 3.1 & 0.124 & 0.108 & 8.2 & 7 & 8.4 \\
\hline SC-092 & Black shales & 80.9 & -31.2 & 0.7 & 0.7 & 1.2 & 0.130 & 0.100 & 6.3 & 13 & 19.5 \\
\hline SC-099 & Black shales & 92.5 & -30.6 & 0.3 & 0.3 & 0.6 & 0.115 & 0.089 & 3.0 & 2 & 7.1 \\
\hline SC-107 & Black shales & 107.5 & -30.2 & 0.4 & 0.4 & 0.5 & 0.068 & 0.054 & 7.5 & 5 & 12.5 \\
\hline SC-109 & Black shales & 111.7 & -30.3 & 0.4 & 0.4 & 0.5 & 0.088 & 0.067 & 5.6 & 2 & 5.1 \\
\hline SC-122 & Black shales & 138.3 & -30.6 & 0.3 & 0.3 & 0.2 & 0.100 & 0.080 & 3.7 & 2 & 6.9 \\
\hline
\end{tabular}

Correspondingly, $\mathrm{Mo} / \mathrm{TOC}_{\text {bulk }}$ ratios increase from 8.3 to 33.8, averaging 18.2 (Fig. 2b).

\section{Discussion}

\subsection{Regional correlation}

Stratigraphic correlation for deep water sections is difficult due to the lack of marker fossils. At Yuanjia section, the PrecambrianCambrian boundary could be placed at the negative $\delta^{13} \mathrm{C}_{\mathrm{org}}$ excursion in the upper Liuchapo Formation (Guo et al., 2013) because this excursion may correlate with the $\delta^{13} \mathrm{C}_{\text {carb }}$ and/or $\delta^{13} C_{\text {org }}$ negative excursions in the Daibu Member of the Zhujiaqing Formation at Xiaotan section, Yunnan Province (Cremonese et al., 2013; Li et al., 2013a; Zhou et al., 1997) and in the lower part of the Yanjiahe Formation at Wuhe section, Three Gorges area (Cremonese et al., 2014; Ishikawa et al., 2008; Kikumoto et al., 2014) (Fig. 3b). The small shelly fossil (SSF) zones I and II were identified at Zhongyicun Member of the Zhujiaqing Formation, Yunnan and lower Yanjiahe Formation, Three Gorges (Fig. 3a) (Guo et al., 2014; Li and Xiao, 2004; Yang et al., 2014). The combination of carbon isotope correlation and SSFs records suggests that the upper Liuchapo Formation belongs to the Cambrian Fortunian Stage (Fig. 3). Upward, the $\delta^{13} C_{\text {org }}$ curve exhibits positive excursions in the Dahai Member of the Zhujiaqing Formation, Yunnan and in the upper Yanjiahe Formation, Three Gorges area (Cremonese et al., 2013, 2014; Kikumoto et al., 2014) (Fig. 3b), which are typical of early Cambrian Stage 2, consistent with the appearance of the third SSF biozone (Fig. 3a) (Guo et al., 2014; Li and Xiao, 2004; Yang et al., 2014).
Unfortunately, these high $\delta^{13} C_{\text {org }}$ values were not observed in our study (Fig. 3b), suggesting that deposits of early Stage 2 are missing at Sancha section on the elevated shelf margins due to erosion, and/or are highly condensed at the Yuanjia section due to the extremely low sedimentary rates in the deeper basinal realm (Jiang et al., 2012; Steiner et al., 2007; Zhu et al., 2003).

The early Cambrian Ni-Mo enrichment layers can be tracked at a $1600 \mathrm{~km}$ belt along the whole southern margin of the Yangtze Platform and can be used as a correlation marker throughout the region (Jiang et al., 2012; Och et al., 2013; Zhu et al., 2003). A ReOs isochron age of $521 \pm 5 \mathrm{Ma}(n=14)$ has been obtained for the sulfide ore layer near the base of the Niutitang Formation from three mining sites, including Sancha section (the other two sites are Dazhuliushui and Maluhe sections) (Xu et al., 2011) (Fig. 3a). This age is consistent with U-Pb SHRIMP ages of $522.7 \pm 4.9 \mathrm{Ma}$ for zircons from a volcanic ash bed approximately one meter below the Ni-Mo layer at Taoying section (Wang et al., 2012b) and of $532.3 \pm 0.7 \mathrm{Ma}$ for zircons from a volcanic ash bed about $5 \mathrm{~m}$ below the Ni-Mo layer at Zhongnancun section (Jiang et al., 2009), both at the base of the Niutitang Formation in Guizhou (Fig. 3a). The correlation between $\mathrm{Ni}-\mathrm{Mo}$ enrichment layers of the basal Niutitang Formation in Hunan and Guizhou provinces and the upper Shiyantou Formation at Xiaotan section in Yunnan by Och et al. (2013) is supported by a $\mathrm{U}-\mathrm{Pb}$ age of $526.5 \pm 1.1 \mathrm{Ma}$ for zircons from a volcanic ash bed within the lower part of the Shiyantou Formation at Meishucun section in Yunnan (Compston et al., 2008) (Fig. 3a). Sediments corresponding to the lower-middle Shiyantou Formation are missing at Sancha section due to the erosional event that started during early Stage 2 as mentioned above, and are highly 
Table 2

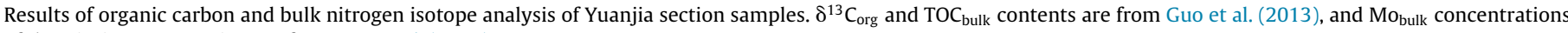
of the Niutitang Formation are from Guo et al. (2015).

\begin{tabular}{|c|c|c|c|c|c|c|c|c|c|c|c|}
\hline \multirow[t]{2}{*}{ Sample } & \multirow[t]{2}{*}{ Lithology } & \multirow{2}{*}{$\begin{array}{l}\text { Depth } \\
(\mathrm{m})\end{array}$} & \multirow{2}{*}{$\begin{array}{l}\delta^{13} C_{\text {org }} \\
(\%)\end{array}$} & \multicolumn{2}{|l|}{ TOC (\%) } & \multirow{2}{*}{$\begin{array}{l}\delta^{15} \mathrm{~N}_{\text {bulk }} \\
(\%)\end{array}$} & \multicolumn{2}{|l|}{ TN (\%) } & \multirow{2}{*}{$\begin{array}{l}\mathrm{C} / \mathrm{N} \text { (atom) } \\
\text { decarb }\end{array}$} & \multirow{2}{*}{$\begin{array}{l}\mathrm{Mo}_{\text {bulk }} \\
(\mathrm{ppm})\end{array}$} & \multirow{2}{*}{$\begin{array}{l}\mathrm{Mo} / \mathrm{TOC}_{\text {bulk }} \\
(\mathrm{ppm} / \%)\end{array}$} \\
\hline & & & & decarb & bulk & & decarb & bulk & & & \\
\hline \multicolumn{12}{|c|}{ Liuchapo Formation } \\
\hline Yuj-503 & Chert & 0 & -33.9 & & & & & & & & \\
\hline Yuj-508 & Chert & 3.5 & -34 & 2.0 & 1.7 & 1.4 & 0.024 & 0.025 & 95.5 & & \\
\hline Yuj-511 & Chert & 6 & -34.1 & 0.7 & & -1.8 & 0.023 & 0.017 & 36.1 & 4.10 & \\
\hline Yuj-516 & Chert & 9.5 & -34.4 & 1.1 & 1.0 & -1.7 & 0.026 & 0.019 & 49.0 & 4.70 & 4.7 \\
\hline Yuj-520 & Chert & 13 & -34.8 & 1.2 & 1.2 & 1.4 & 0.040 & 0.028 & 35.8 & & \\
\hline Yuj-522 & Chert & 14 & -34.4 & 1.3 & 1.3 & -2.1 & 0.027 & 0.017 & 57.4 & 2.20 & 1.8 \\
\hline Yuj-524 & Chert & 15 & -33.1 & 3.5 & 3.6 & 0.3 & 0.047 & 0.030 & 87.9 & & \\
\hline Yuj-526 & Chert & 16 & -32.8 & 1.9 & 1.8 & -3 & 0.027 & 0.017 & 83.4 & 8.70 & 4.8 \\
\hline Yuj-527 & Chert & 16.5 & -33 & 2.8 & 2.7 & -4.3 & 0.027 & 0.013 & 120.0 & 15.6 & 5.7 \\
\hline Yuj-529 & Shaly chert & 17.5 & -32.9 & 7.2 & 6.9 & -2.1 & 0.069 & 0.024 & 122.2 & 16.6 & 2.4 \\
\hline Yuj-531 & Cherty black shale & 18.15 & -32.3 & 6.6 & 6.1 & -0.5 & 0.071 & 0.047 & 108.5 & 30.2 & 5.0 \\
\hline \multicolumn{12}{|c|}{ Niutitang Formation } \\
\hline Yuj-532 & Phosphoritic black shale & 18.2 & -32.8 & 6.5 & 6.3 & 0.7 & 0.063 & 0.055 & 121.1 & 33.0 & 5.2 \\
\hline Yuj-533 & Black shale & 18.45 & -32.9 & 5.8 & 5.7 & 1 & 0.061 & 0.056 & 110.0 & 28.5 & 5.0 \\
\hline Yuj-534 & Black shale & 18.65 & -32.9 & 3.6 & 3.4 & -1.6 & 0.034 & 0.024 & 123.0 & 15.0 & 4.4 \\
\hline Yuj-535 & Black shale & 19 & -32.4 & 6.3 & 5.8 & 0 & 0.069 & 0.037 & 106.2 & & \\
\hline Yuj-536 & Black shale & 19.3 & -32.9 & 17.5 & 19.5 & -0.6 & 0.161 & 0.068 & 126.6 & 271 & 13.9 \\
\hline Yuj-537 & Black shale & 19.6 & -32.4 & 25.8 & 16.9 & 1.6 & 0.311 & 0.117 & 96.9 & & \\
\hline Yuj-543 & Black shale & 21.2 & -32 & 12.8 & 12.6 & -0.5 & 0.135 & 0.074 & 110.3 & 17.1 & 1.4 \\
\hline Yuj-545 & Black shale & 21.6 & -32 & 14.9 & 14.9 & 0 & 0.170 & 0.089 & 101.9 & & \\
\hline Yuj-549 & Stone coal & 22.5 & -32 & 15.8 & 16.9 & 1.3 & 0.223 & 0.121 & 82.7 & 19.6 & 1.2 \\
\hline Yuj-554 & Black shale & 23.7 & -31.8 & 14.4 & 16.7 & 2 & 0.227 & 0.152 & 73.8 & & \\
\hline Yuj-557 & Black shale & 24.5 & -31.7 & 17.5 & 13.2 & 1.4 & 0.195 & 0.091 & 104.8 & 50.9 & 3.9 \\
\hline Yuj-559 & Black shale & 26.5 & -31.4 & 18.8 & 19.0 & 2.2 & 0.256 & 0.183 & 85.7 & & \\
\hline Yuj-563 & Black shale & 28.5 & -31.3 & 5.9 & 4.7 & & & & & 2.21 & 0.5 \\
\hline Yuj-565 & Black shale & 29.5 & -30.6 & 2.2 & 2.1 & & & & & 2.93 & 1.4 \\
\hline Yuj-568 & Black shale & 30.5 & -31.5 & 10.0 & 9.8 & & & & & 17.7 & 1.8 \\
\hline Yuj-570 & Black shale & 31.5 & -32 & 13.1 & 12.5 & 1.6 & 0.334 & 0.236 & 45.9 & & \\
\hline Yuj-571 & Black shale & 32.5 & -32.3 & 14.8 & 14.5 & 1.6 & 0.303 & 0.202 & 56.9 & 100 & 6.9 \\
\hline Yuj-573 & Black shale & 33.2 & -32.5 & 12.4 & 12.4 & 1.3 & 0.269 & 0.182 & 53.7 & 92.0 & 7.4 \\
\hline Yuj-575 & Black shale & 34.1 & -33.6 & 9.4 & 9.2 & 1.2 & 0.216 & 0.147 & 50.9 & 11.0 & 1.2 \\
\hline Yuj-579 & Black shale & 36 & -32.3 & 14.6 & 14.8 & 0.1 & 0.297 & 0.189 & 57.2 & 65.4 & 4.4 \\
\hline Yuj-580 & Black shale & 37.05 & -32.7 & 17.8 & & 0.9 & 0.307 & 0.208 & 67.7 & & \\
\hline Yuj-581 & Black shale & 38.3 & -33.4 & 16.5 & 12.4 & 0.4 & 0.430 & 0.238 & 44.9 & & \\
\hline Yuj-583 & Black shale & 39.7 & -33.3 & 12.9 & 12.2 & 1.6 & 0.333 & 0.249 & 45.1 & 81.6 & 6.7 \\
\hline Yuj-584 & Black shale & 40.5 & -33.1 & 12.8 & 12.3 & 1.5 & 0.324 & 0.242 & 45.9 & & \\
\hline Yuj-586 & Black shale & 42.5 & -32.9 & 15.4 & 14.6 & 0.7 & 0.277 & 0.187 & 64.8 & & \\
\hline Yuj-587 & Black shale & 43.85 & -32.6 & 16.5 & 14.6 & 1.3 & 0.312 & 0.201 & 61.5 & 143 & 9.8 \\
\hline Yuj-588 & Black shale & 44.5 & -32.8 & 14.7 & 13.6 & 1.8 & 0.417 & 0.307 & 41.3 & & \\
\hline Yuj-589 & Black shale & 45.5 & -32.9 & 12.4 & 11.9 & 1 & 0.235 & 0.170 & 61.6 & & \\
\hline Yuj-591 & Black shale & 46.5 & -33.2 & 12.8 & 12.1 & 1.4 & 0.306 & 0.227 & 48.7 & & \\
\hline Yuj-592 & Black shale & 49 & -32.9 & 12.1 & 11.1 & 0.6 & 0.309 & 0.218 & 45.9 & & \\
\hline Yuj-593 & Black shale & 51.5 & -32.2 & 12.1 & 11.9 & -0.8 & 0.106 & 0.050 & 133.5 & & \\
\hline Yuj-594 & Black shale & 53.5 & -32 & 12.3 & 11.3 & 1 & 0.266 & 0.190 & 54.0 & & \\
\hline Yuj-595 & Black shale & 56.5 & -31.9 & 13.2 & 12.1 & 0.5 & 0.270 & 0.175 & 57.2 & 254 & 21.0 \\
\hline Yuj-596 & Black shale & 58.5 & -31.3 & 26.3 & 22.5 & -0.2 & 0.300 & 0.141 & 102.4 & & \\
\hline Yuj-597 & Black shale & 61 & -31.7 & 14.8 & 13.4 & -0.6 & 0.252 & 0.157 & 68.7 & 453 & 33.8 \\
\hline Yuj-598 & Black shale & 63.5 & -31.6 & 9.6 & 7.3 & -2.4 & 0.188 & 0.099 & 59.9 & & \\
\hline Yuj-599 & Black shale & 65.5 & -31.7 & 6.5 & 6.6 & -2.2 & 0.100 & 0.061 & 76.1 & & \\
\hline Yuj-601 & Black shale & 69.5 & -31.7 & 8.6 & 7.9 & -1.2 & 0.161 & 0.123 & 62.2 & 65.3 & 8.3 \\
\hline Yuj-602 & Black shale & 70.7 & -31.5 & 10.6 & 10.4 & -3 & 0.151 & 0.053 & 81.8 & & \\
\hline
\end{tabular}

condensed at Yuanjia section due to extremely low sedimentary rates in the deep water realm (Jiang et al., 2012; Steiner et al., 2007; Zhu et al., 2003). Thus, the Ni-Mo enrichment layer at the base of Niutitang Formation in our study likely belongs to the later portion of Cambrian Stage 2 (Fig. 3).

The early Cambrian deep basinal sediments of the Niutitang Formation in Hunan are poor in fossils compared with equivalent shallow water successions. Based on the similar increasing trend in $\delta^{13} C_{\text {org }}$ in this study and at Xiaotan section (Cremonese et al., 2013), the lower-middle part of the Niutitang Formation in Hunan could be approximately correlated with the basal Yu'anshan Formation in northeastern Yunnan (Fig. 3b). The Yu'anshan Formation belongs to Stage 3 and the middle and upper part of this formation in eastern Yunnan contains the famous Chengjiang fauna (Zhang and Hou, 1985). According to studies of sponges and SSF fragments at the Sancha section, the upper part of the Niutitang Formation may be approximately correlated with the middle-upper part of the Yu'anshan Formation in Yunnan (Steiner et al., 2005, 2007) (Fig. 3a). In addition, the lower Shuijingtuo Formation in Hubei province contains the Rhombocorniculum cancellatum taxon-range Zone as well as trilobites and so already belongs to Stage 3 (Qiongzhusian Stage) (Guo et al., 2014; Steiner et al., 2007) (Fig. 3a). Therefore, we correlate the upper Niutitang Formation at Sancha and Yuanjia sections with the Shuijingtuo Formation in the Three Gorges area and the middle-upper part of the Yu'anshan Formation in Yunnan (Fig. 3).

\subsection{Evaluation of nitrogen isotope data}

Microbial degradation of organic matter during early diagenesis and thermal maturation during burial may have modified nitrogen 


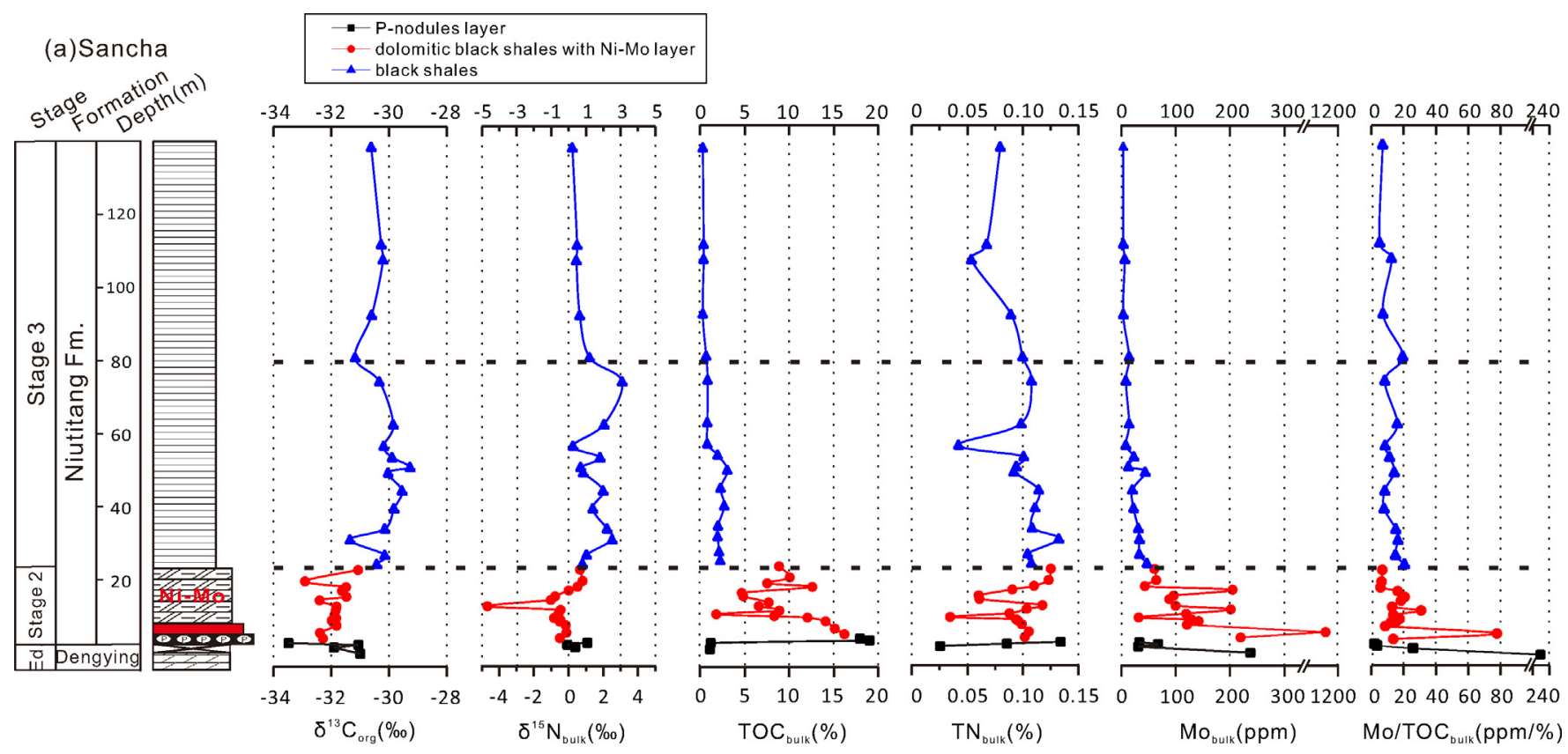

(b)Yuanjia
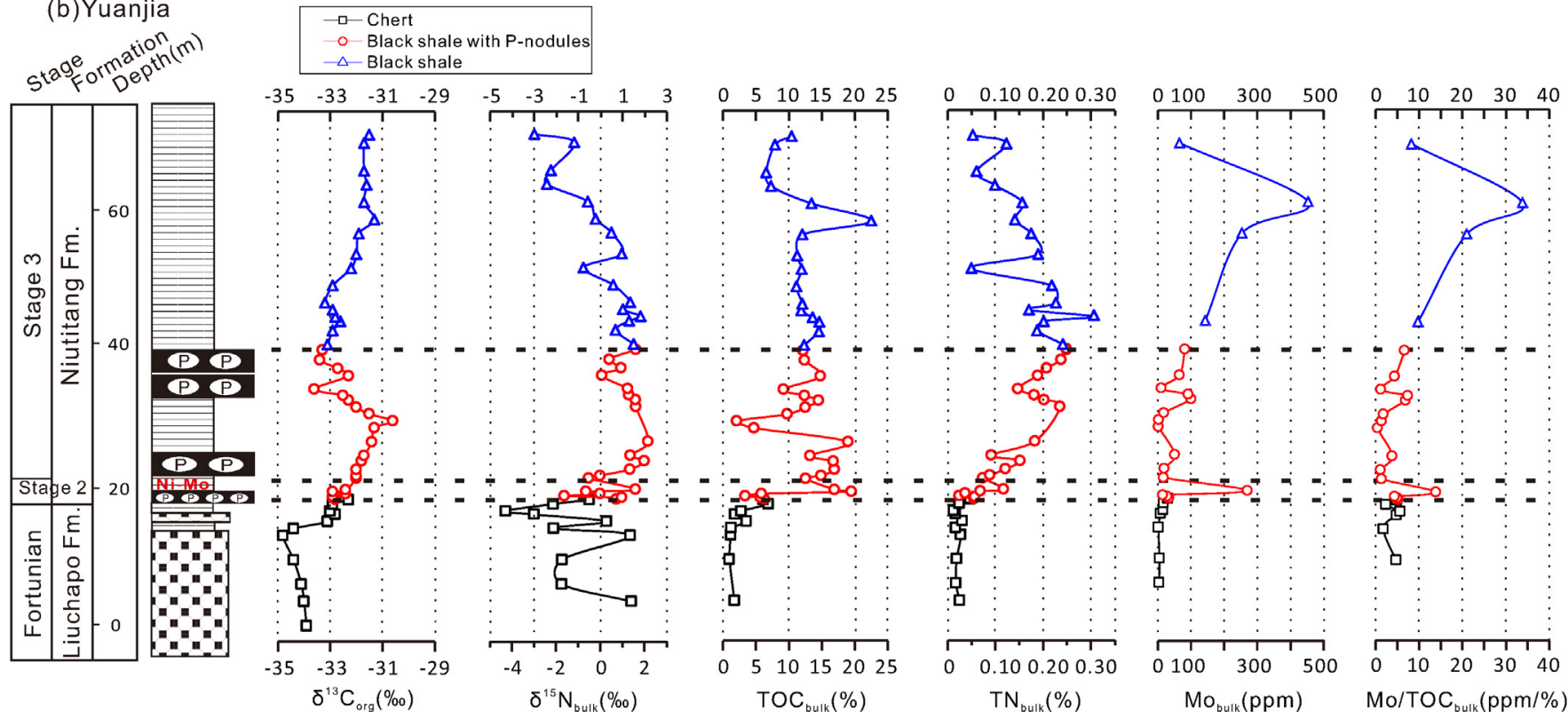

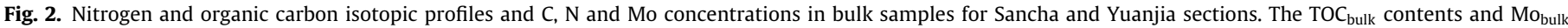

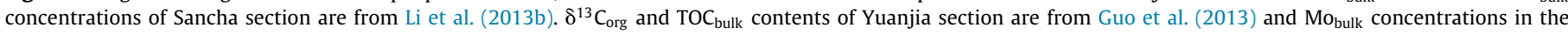
Niutitang Formation of Yuanjia section are from Guo et al. (2015).

contents and possibly their isotopic compositions as well. To make sure whether our nitrogen isotopic data are reliable and record the primary marine signals, we will first discuss the $\mathrm{TOC}_{\text {decarb }}, \mathrm{TN}_{\mathrm{decarb}}$ contents, $\mathrm{C} / \mathrm{N}_{\text {decarb }}$ (atom) ratios and their relationships with nitrogen isotopic compositions.

For Sancha and Yuanjia sections, plots of $\mathrm{TN}_{\text {decarb }}-\mathrm{TOC}_{\text {decarb }}$ show rough linear correlations (Fig. $4 \mathrm{a}$ and d), indicating that the nitrogen mainly originated from primary organic matter (Calvert, 2004). The intercepts on the TN axis reflect inorganic clay-bound nitrogen components (Fig. 4a and d), which were mostly derived from the digestion of organic matter by microorganisms (Macko et al., 1986).

Normal marine mean $\mathrm{C} / \mathrm{N}$ ratio of organic matter in modern oceans is $\sim 6.6$ (Redfield, 1963). Loss of $\mathrm{N}$ may lead to high $\mathrm{C} / \mathrm{N}$ ratios and result in the alteration of $\mathrm{N}$ isotopic records. The $\mathrm{C} / \mathrm{N}_{\mathrm{decarb}}$ ratios range from 3.0 to 293.9 with a mean value of 61.5 in the Sancha section and from 35.8 to 133.5 with a mean value of 76.7 in the Yuanjia section, similar to other typically high Precambrian C/N ratios (>100) (Beaumont and Robert, 1999; Garvin et al., 2009; Papineau et al., 2009). In Sancha section, the $\mathrm{C} / \mathrm{N}_{\text {decarb }}$ ratios exhibit a strong linear correlation with $\mathrm{TOC}_{\text {decarb }}$ contents, except for the lowermost phosphorus-nodules layer (Fig. 4b). For the Yuanjia section, there is linear correlation between $\mathrm{C} / \mathrm{N}_{\mathrm{decarb}}$ ratios and $\mathrm{TOC}_{\text {decarb }}$ contents in the upper Liuchapo Formation (Fig. 4e), and significant co-variation between $\mathrm{N} / \mathrm{C}_{\text {decarb }}$ ratios and $\mathrm{TN}_{\mathrm{decarb}}$ contents for the black shales in the Niutitang Formation (Fig. 4f). These linear correlations imply preferential loss of organic $\mathrm{N}$ from the sediments during diagenesis and/or thermal metamorphism. Fortunately, plots of $\delta^{15} \mathrm{~N}_{\text {bulk }}-\mathrm{TOC}_{\text {decarb }}, \delta^{15} \mathrm{~N}_{\text {bulk }}-\mathrm{TN}_{\text {decarb }}$ and $\delta^{15} \mathrm{~N}_{\text {bulk }}-\mathrm{C} / \mathrm{N}_{\text {decarb }}$ exhibit no linear correlation for the 
Eastern Yunnan

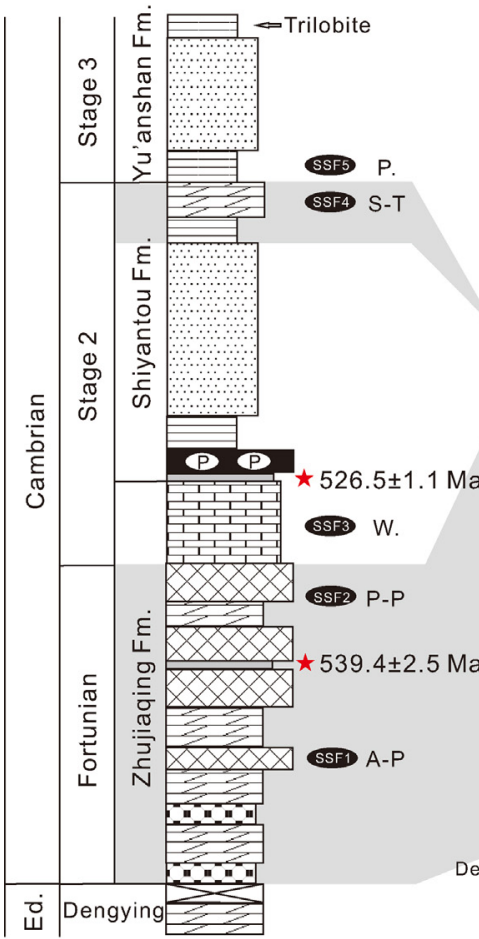

\section{Three Gorges}

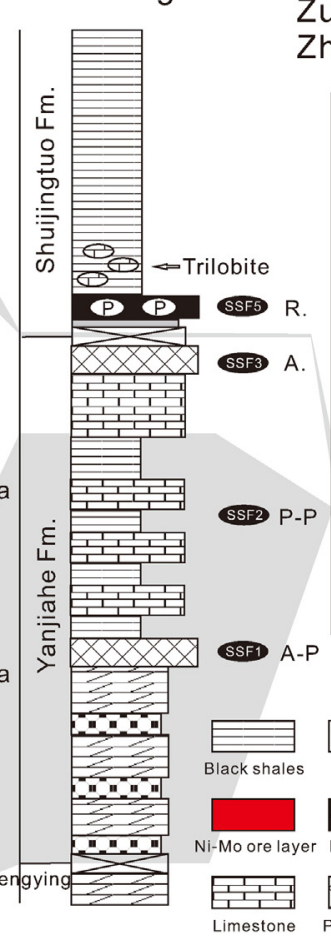

\section{Zunyi, Guizhou \&} Zhangjiajie, Hunan

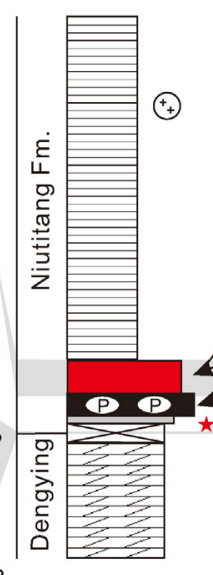

(a)

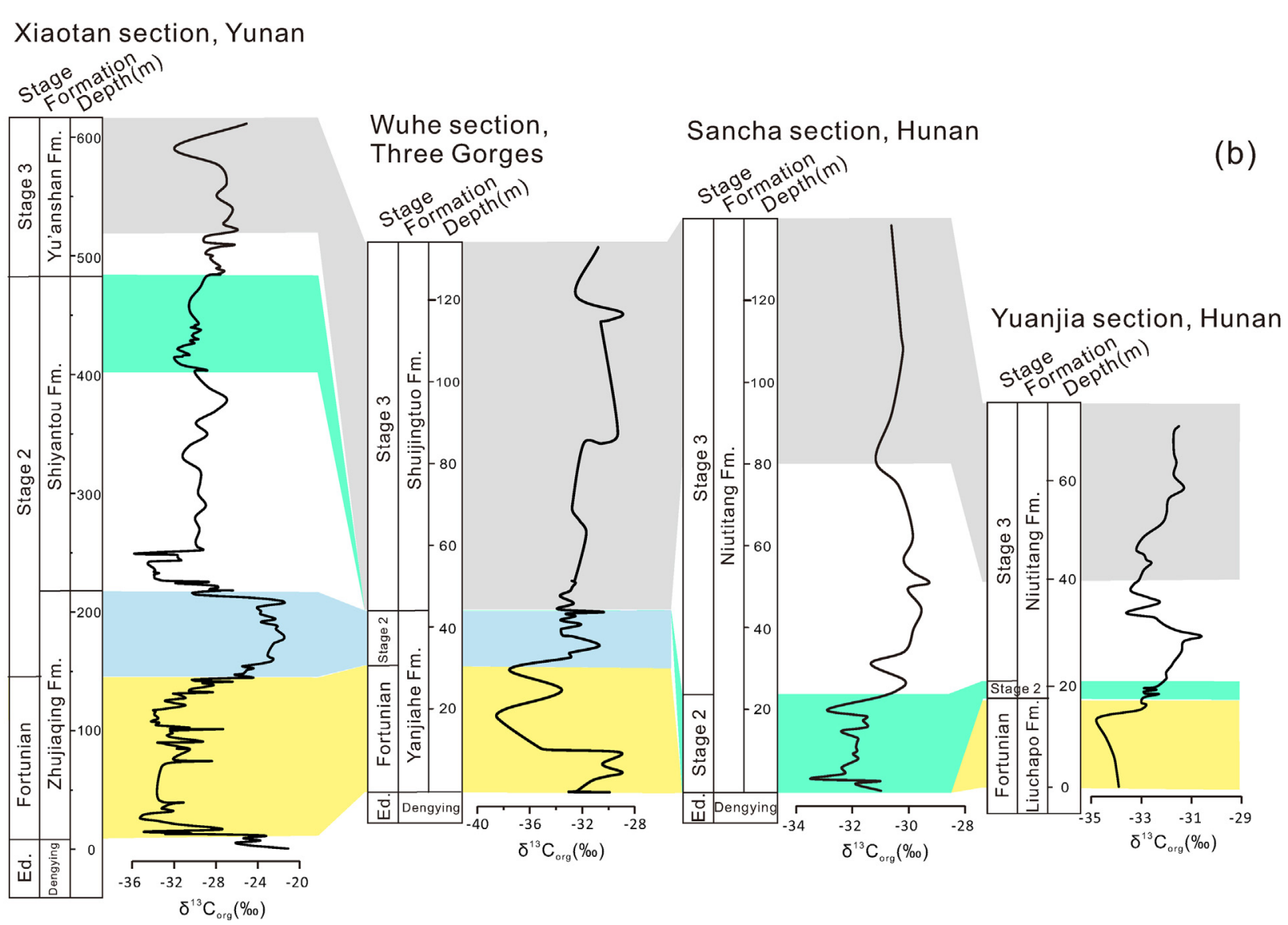

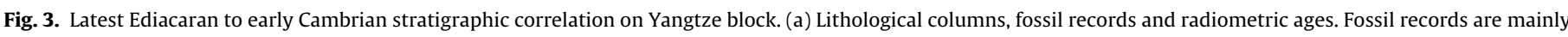

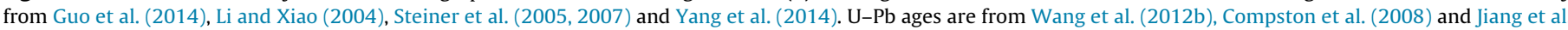

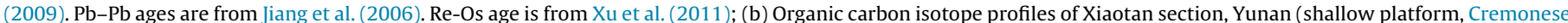

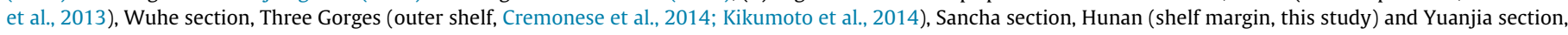
Hunan (deep basin, this study). 

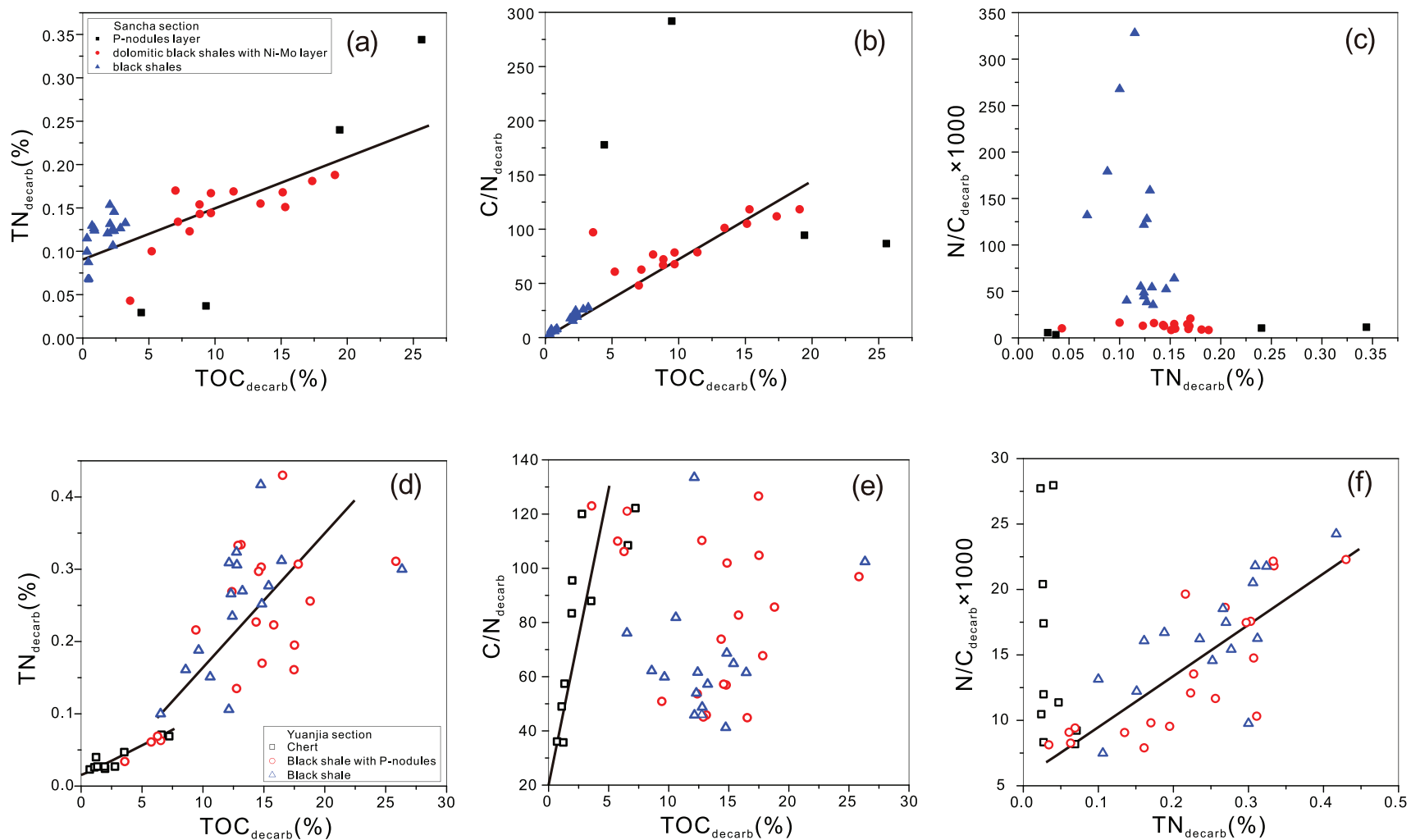

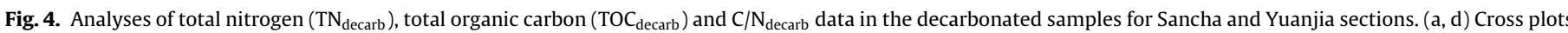
of $\mathrm{TN}_{\text {decarb }}$ versus $\mathrm{TOC}_{\text {decarb}}$. (b, e) Cross plots of $\mathrm{C} / \mathrm{N}_{\text {decarb }}$ versus $\mathrm{TOC}_{\text {decarb}}$. $(c, f)$ Cross plots of N/C $\mathrm{C}_{\text {decarb }}$ versus $\mathrm{TN}_{\mathrm{dec}}$.
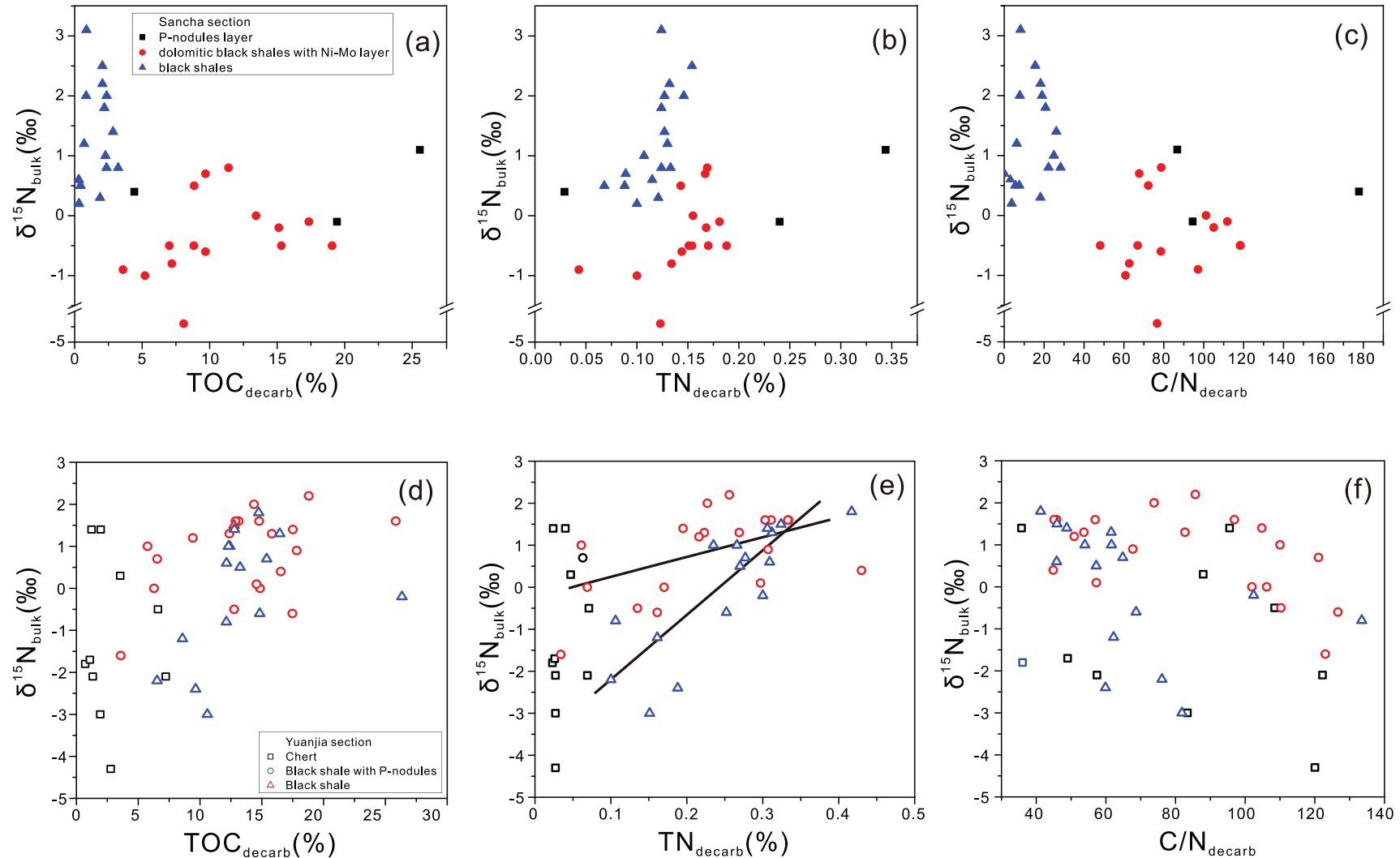

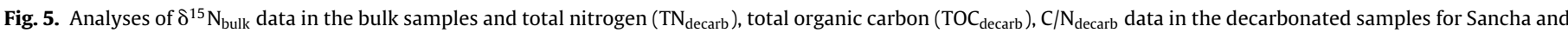
Yuanjia sections. (a, d) Cross plots of $\delta^{15} \mathrm{~N}_{\text {bulk }}$ versus TOC decarb. (b, e) Cross plots of $\delta^{15} \mathrm{~N}_{\text {bulk }}$ versus TN $\mathrm{N}_{\text {decarb }}$. (c, f) Cross plots of $\delta^{15} \mathrm{~N}_{\text {bulk }}$ versus C/N $\mathrm{N}_{\text {decarb }}$. 
Sancha section (Fig. 5a-c), implying that the primary nitrogen isotope compositions were not modified significantly during diagenesis. However, for the Yuanjia section, $\delta^{15} \mathrm{~N}_{\text {bulk }}$ values do show weak positive correlations with $\mathrm{TN}_{\text {decarb }}$ contents in the lower Niutitang Formation and a stronger positive correlation in the upper Niutitang Formation (Fig. 5e). These positive correlations cannot be explained either by post-depositional remineralization or by thermal metamorphism, since $\delta^{15} \mathrm{~N}_{\text {bulk }}$ values in sediments normally increase with decreasing $\mathrm{TN}_{\mathrm{dec}}$ carb content due to the preferential loss of ${ }^{14} \mathrm{~N}$ during alteration, thus causing negative correlations (Möbius, 2013; Pinti et al., 2007; Thomazo et al., 2011). Instead, the positive correlation between $\delta^{15} \mathrm{~N}_{\text {bulk }}$ and $\mathrm{TN}_{\text {decarb }}$ contents could reflect two end-members of nitrogen source in the bulk sediments under varying redox conditions. Ammonium or atmospheric $\mathrm{N}_{2}$ with low $\delta^{15} \mathrm{~N}$ values contributed as the main nitrogen source under anoxic conditions, while ${ }^{15} \mathrm{~N}$-enriched nitrate was the dominant source under oxic conditions. Thus the observed $\mathrm{TN}_{\text {decarb }}-\delta^{15} \mathrm{~N}_{\text {bulk }}$ trend recorded by the Yuanjia section could probably result from the redox conditions in the photic zone shifting between anoxic and oxic during different time periods.

Based on published Fe speciation data (Canfield et al., 2008; Chen et al., 2015; Feng et al., 2014; Jin et al., 2014; Och, 2011; Och et al., 2013; Wang et al., 2012a), the Liuchapo and Niutitang formations (and correlative formations) were mostly deposited under anoxic conditions. Anaerobic degradation of organic matter during early diagenesis retains the initial $\delta^{15} \mathrm{~N}$ value or decreases $\delta^{15} \mathrm{~N}$ only to a slight extent (less than $2 \%$ ) (Freudenthal et al., 2001; Möbius et al., 2010; Robinson et al., 2012). On the other hand, although thermal metamorphism can increase $\mathrm{C} / \mathrm{N}$ ratios to hundreds and even thousands, $\delta^{15} \mathrm{~N}$ values might only increase to a small extent, depending on metamorphic grade, with increases of $\sim 1-2 \%$ at greenschist facies and of $\sim 3-4 \%$ at amphibolite facies (Bebout and Fogel, 1992; Jia, 2006; Mingram and Bräuer, 2001). As the $\delta^{15} \mathrm{~N}_{\text {bulk }}$ values from our studied successions are unlikely to have been modified significantly by post-depositional thermal alteration because of high $\mathrm{H} / \mathrm{C}$ ratio values having been measured at the nearby coeval Yanwutan-Lijiatuo section (Guo et al., 2007b), nitrogen isotopic shifts if any caused by thermal alteration should be expressed consistently through the section in such a limited stratigraphic interval.

Based on the discussion above, although the preferential loss of nitrogen during depositional and post-depositional processes may have modified $\delta^{15} \mathrm{~N}_{\text {bulk }}$ values of the studied samples, such modifications would have been only of minor import. Thus, our $\delta^{15} \mathrm{~N}$ data have the potential to record the primary signals for the early Cambrian ocean along the southern margin of the Yangtze platform.

\subsection{Paleoenvironmental implications of $\delta^{15} N_{\text {bulk }}$ and $\delta^{13} C_{\text {org }}$ variations}

Based on the stratigraphic correlations above in Section 5.1, the paleoenvironmental implications of the $\delta^{13} C_{\text {org }}$ and $\delta^{15} \mathrm{~N}_{\text {bulk }}$ variations during different intervals are discussed and explored below and a plausible $\mathrm{N}$ cycle model for the early Cambrian basin along the southern margin of the Yangtze platform is then proposed.

\subsubsection{Cambrian Fortunian Stage}

Currently available Fe speciation data indicate that euxinic waters were not widespread during the latest Ediacaran - the earliest Cambrian interval and that the water column was stratified with an oxygenated upper layer overlying a ferruginous deepwater column in the basin of South China (Canfield et al., 2008; Chen et al., 2015; Feng et al., 2014; Goldberg et al., 2007; Och, 2011; Och et al., 2013; Wang et al., 2012a) (Fig. 6a). Low Mobulk concentrations and $\mathrm{Mo} / \mathrm{TOC}_{\text {bulk }}$ ratios at the upper Liuchapo Formation in Yuanjia section are consistent with this speculation
(Fig. 2b). In such a stratified basin, ammonia could accumulate to a high concentration in anoxic deep waters, while nitrate would be present in oxygenated surface water, analogous to the modern Matano Lake in Indonesia (Crowe et al., 2011). In this interval, $\delta^{15} \mathrm{~N}_{\text {bulk }}$ values vary greatly from $-4.3 \%$ o to $+2 \%$ o in the Yuanjia section (Fig. 2b), implying an unstable redox transition zone in the surface mixed layer, which broadly corresponds to the photic zone (Ader et al., 2014) (Fig. 6a). In this case, the nitrate reservoir is likely to have been small, and was either reduced to ammonia by mixed $\mathrm{Fe}(\mathrm{II}) /(\mathrm{III})$ oxy(hydr)oxide species through abiotic processes (Hansen et al., 1996), or converted to $\mathrm{NO}_{2}{ }^{-} / \mathrm{N}_{2} / \mathrm{NH}_{4}{ }^{+}$mediated by anaerobic nitrate-dependent $\mathrm{Fe}(\mathrm{II})$-oxidizing microorganisims under dominantly ferruginous conditions (Busigny et al., 2013; Shen et al., 2013; Straub et al., 1996; Weber et al., 2006a,b) (Fig. 6a), although nitrogen isotopic fractionation effects associated with these processes are still unclear. Ammonia would have been competitively assimilated by organisms and converted to $\mathrm{N}_{2}$ through anammox (Ader et al., 2014) (Fig. 6a). According to such a scenario, low $\delta^{15} \mathrm{~N}_{\text {bulk }}$ values ( $-4 \%$ o to $-2 \%$ ) may result from partial assimilation of ammonia with a large isotopic fractionation effect (Crowe et al., 2008b; Higgins et al., 2012; Kappler et al., 2005), while high $\delta^{15} \mathrm{~N}_{\text {bulk }}$ values around +2\% would mainly be due to the assimilation of ${ }^{15} \mathrm{~N}$-enriched ammonia by anaerobic organisms such as green and purple bacteria (Crowe et al., 2008b; Kappler et al., 2005). Thus, $\delta^{15} \mathrm{~N}_{\text {bulk }}$ fluctuations may thus be explained by competition between ammonia assimilation and anammox metabolisms under anoxic conditions.

$\delta^{13} C_{\text {org }}$ values are low ( $-35 \%$ o to $-33 \%$ ) and exhibit a negative shift (Fig. 2b) that could result from the assimilation of ${ }^{12} \mathrm{C}$-enriched inorganic carbon by anaerobic organisms (Küspert, 1982; Schouten et al., 2000; Struck et al., 2001) (Fig. 6a). This suggests that an isotopically light dissolved inorganic carbon (DIC) pool impinged on the photic zone, consistent with the scenario of a shoaling chemocline (separating ferruginous deep waters from oxygenated surface waters) within the surface mixed layer as implied by $\delta^{15} \mathrm{~N}_{\text {bulk }}$ data above.

\subsubsection{Cambrian Stage 2}

It has been postulated that a mid-depth zone of euxinic water sandwiched between oxic surface waters and ferruginous deep waters developed in the early Cambrian due to an increasing sulfate supply from weathering, which then greatly expanded during worldwide transgression in Cambrian Stage 2 (Feng et al., 2014; Jin et al., 2014). This expansion was developed widely from the shelf margin to the slope-basin areas of the South China basin as evidenced by iron speciation and Mo chemistry data (Canfield et al., 2008; Chen et al., 2015; Feng et al., 2014; Guo et al., 2007a; Och, 2011; Och et al., 2013) (Fig. 6b). A Ni-Mo enrichment layer along the transitional zone between the platform and basin was deposited under these euxinic conditions (Lehmann et al., 2007; Steiner et al., 2001). Previous studies argued that the Ni-Mo enrichments in the sediments could originate from hydrothermal input (Lott et al., 1999; Steiner et al., 2001), enrichment from seawater (Lehmann et al., 2007; Mao et al., 2002), or more likely the combination of both processes (Pašava et al., 2008). Recent studies demonstrated that the Ni-Mo sulfide ore layer, which is usually less than half meters in thickness (Jiang et al., 2006), has relatively lower $\delta^{98}$ Mo values (<1.6\%) (Lehmann et al., 2007; Xu et al., 2012) (low-temperature hydrothermal fluids $\delta^{98} \mathrm{Mo}=+0.8 \%$, McManus et al., 2002), while black shales above and below this $\mathrm{Ni}-\mathrm{Mo}$ ore layer have high $\delta^{98}$ Mo values ( 1.9-2.4\%) (Chen et al., 2015) (modern seawater $\delta^{98} \mathrm{Mo}=+2.34 \%$, Goldberg et al., 2013), suggesting that hydrothermal input of Mo may have contributed only to the Ni-Mo ore layer, but not to the adjacent black shales (Chen et al., 2015). Thus Mo enrichment in the black shales resulted from redox processes and could provide information about the 
(a)
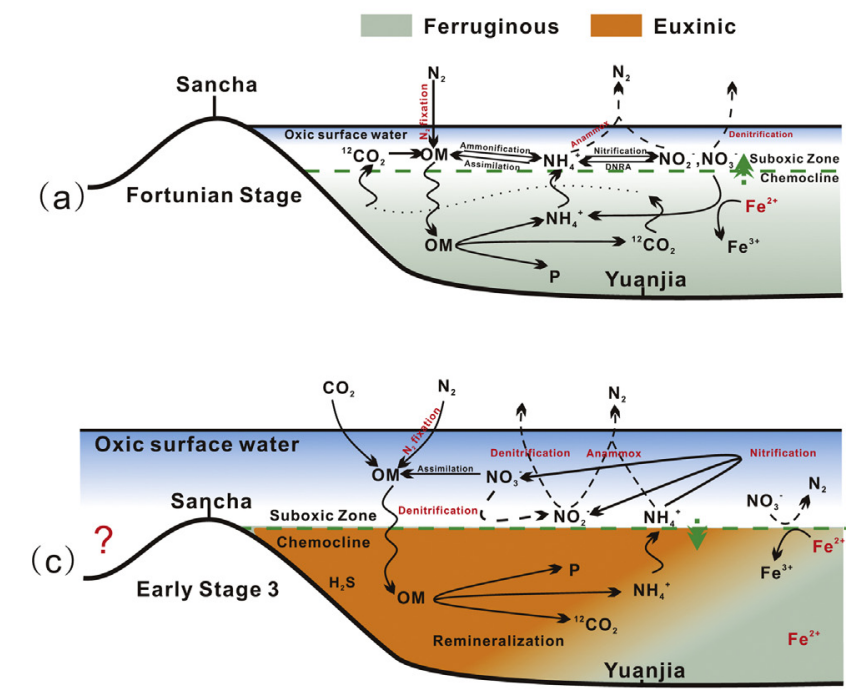

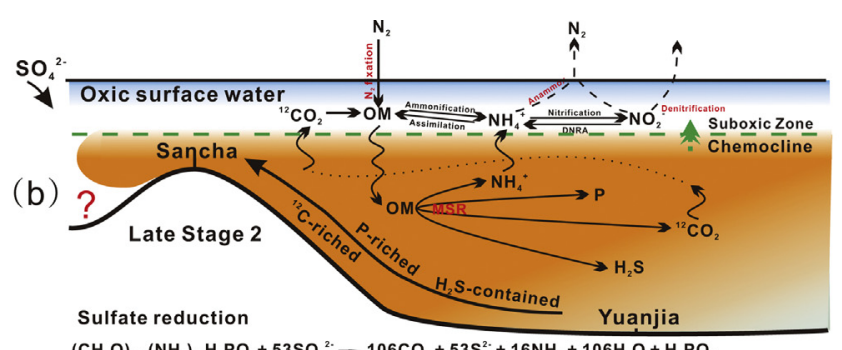

$\left(\mathrm{CH}_{2} \mathrm{O}\right)_{106}\left(\mathrm{NH}_{3}\right)_{16} \mathrm{H}_{3} \mathrm{PO}_{4}+53 \mathrm{SO}_{4}{ }^{2 .}-106 \mathrm{CO}_{2}+53 \mathrm{~S}^{2}+16 \mathrm{NH}_{3}+106 \mathrm{H}_{2} \mathrm{O}+\mathrm{H}_{3} \mathrm{PO}_{4}$

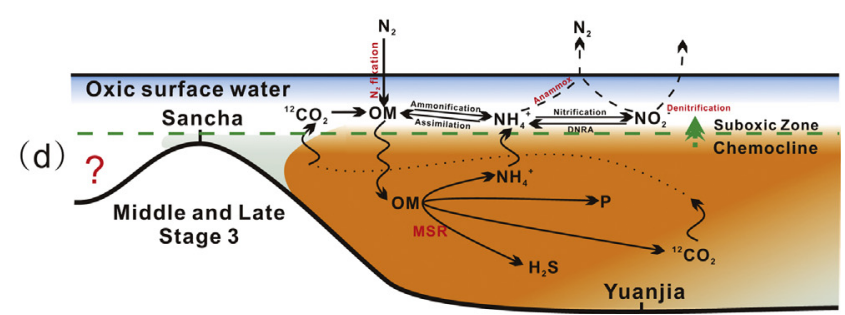

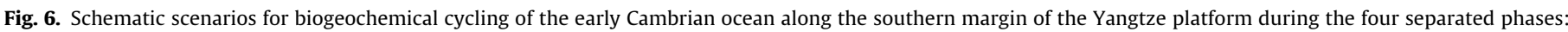

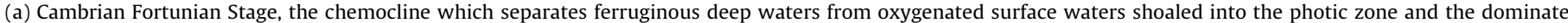

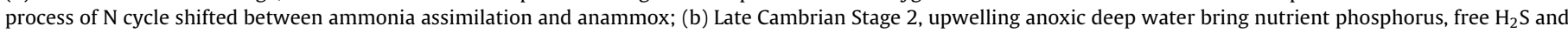

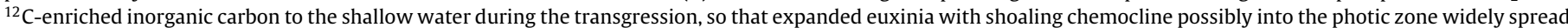

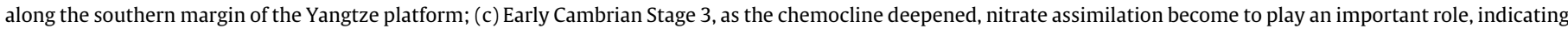

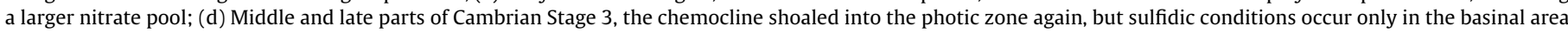
and had not influenced the shelf margin yet.

ocean Mo reservoir. In this study, high $\mathrm{Mo}_{\text {bulk }}$ concentrations $(>100 \mathrm{ppm})$ in the black shales at both Sancha and Yuanjia section (Fig. 2) lend support for widespread euxinic conditions of the basin during this time interval (Scott et al., 2008; Scott and Lyons, 2012) (Fig. 6b). The lower Mo/TOC bulk $(\sim 1-14)$ in the Yuanjia section than that (averaging $\sim 27$ ) in the Sancha section (Fig. 2) could result from the aqueous Mo depletion in the hydrographically restricted deeper watermass (Algeo and Lyons, 2006; Algeo and Rowe, 2012). Deepwater restriction could probably due to the existence of submersed Cathaysia block southeast to the Yangtze block (Li et al., 1996; Wang and Li, 2003), limiting deep water exchange between the basin and the open ocean, although the exact location of Cathaysia block are still unclear.

At the Sancha section, $\delta^{15} \mathrm{~N}_{\text {bulk }}$ values are close to zero with a lowest value of $-4.7 \%$, and $\delta^{13} C_{\text {org }}$ values are also low, at -33.5 to $-31.0 \%$ (Fig. 2a). At the Yuanjia section, the analyzed data exhibit a similar pattern $\left(\delta^{15} \mathrm{~N}_{\text {bulk }}\right.$ values near zero with low $\delta^{13} \mathrm{C}_{\text {org }}$ values around $-32.5 \%$ ) (Fig. $2 \mathrm{~b}$ ), but these data may have not fully recorded the biogeochemical signature of the deep water realm because of the extremely condensed nature of sedimentary deposition due to a rapid rise in sea level (Goldberg et al., 2007; Schütter, 1998; Steiner et al., 2001, 2007). The $\delta^{15} \mathrm{~N}_{\text {bulk }}$ signature which is close to the $\delta^{15} \mathrm{~N}$ value of air ( $0 \%$ ) indicates that biologically available nitrogen mainly came from $\mathrm{N}_{2}$-fixation by diazotrophic cyanobacteria accompanied by little or no isotopic fractionation (Sigman et al., 2009). Owing to the high energy demand of breaking the molecular nitrogen bond, $\mathrm{N}_{2}$-fixation can only occur when fixed-N (nitrate and ammonia) concentrations are low, and nutrient phosphorus is in excess supply (Tyrrell, 1999). This means that fixed-N (nitrate and ammonia) in the surface water most likely had been consumed by intense denitrification and/or anammox processes (Junium and Arthur, 2007; Luo et al., 2011) while phosphorus was efficiently recycled under anoxic conditions (Ingall et al., 1993; Van Cappellen and Ingall, 1994). In the early Cambrian, increasing weathering sulfate flux into the ocean (Feng et al., 2014; Jin et al., 2014) and high TOC (Fig. 2) stimulated intensive microbial sulfate reduction (MSR). When heterotrophic organisms such as sulfate reducing microbes (BSM) decompose the organic matter sinking into the stratified anoxic deep water, an isotopically light DIC repository forms (Fry et al., 1991; Velinsky and Fogel, 1999), and at the same time ammonia, free $\mathrm{H}_{2} \mathrm{~S}$ and phosphorus are released as well [sulfate reduction: $\left(\mathrm{CH}_{2} \mathrm{O}\right)_{106}\left(\mathrm{NH}_{3}\right)_{16} \mathrm{H}_{3} \mathrm{PO}_{4}+53 \mathrm{SO}_{4}{ }^{2-}=106 \mathrm{CO}_{2}+54 \mathrm{~S}^{2-}+16 \mathrm{NH}_{3}$ $+106 \mathrm{H}_{2} \mathrm{O}+\mathrm{H}_{3} \mathrm{PO}_{4}$ ] (Jenkyns et al., 2001) (Fig. 6b). During the transgression at this interval, upwelling anoxic deep waters brought nutrient phosphorus, free $\mathrm{H}_{2} \mathrm{~S}$ and ${ }^{12} \mathrm{C}$-enriched inorganic carbon to the shallow water realm (Fig. 6b). Nutrient phosphorus boosted marine productivity, enhancing deep-water anoxia, which in turn encouraged benthic phosphorus regeneration in a process of positive feedback (Calvert et al., 1996; Ingall and Jahnke, 1994; Ingall and Van Cappellen, 1990; Murphy et al., 2000) (Fig. 7). The key to this positive loop is the transfer of phosphorus from deep anoxic waters to the photic zone (Calvert et al., 1996; Ingall and Jahnke, 1994) (Fig. 6b), which is demonstrated by the widespread phosphorite layers and nodules across the Yangtze Platform produced by upwelling P-replete water interacting with oxygenated surface waters (Wille et al., 2008). Enhanced marine productivity has been suggested by very high TOC $_{\text {bulk }}$ contents in this interval (Fig. 2). Low $\delta^{13} C_{\text {org }}$ values are consistent with the assimilation of the ${ }^{12} \mathrm{C}$-enriched inorganic carbon brought up to the photic zone by upwelling (Fig. 6b). The extremely low $\delta^{15} \mathrm{~N}_{\text {bulk }}$ value of $-4.7 \%$ at Sancha section may have been produced by green or purple sulfur bacteria participating in ammonia assimilation with a large fractionation (Ohkouchi et al., 2005; Pennock et al., 1996) when upwelling currents were vigorous enough for some ammonia to reach the surface water before being converted to $\mathrm{N}_{2}$ (Ader et al., 2014) (Fig. 6b). Therefore, the $\delta^{15} \mathrm{~N}_{\text {bulk }}$ and $\delta^{13} \mathrm{C}_{\text {org }}$ variations suggest enhanced oceanic anoxia and a rise of the chemocline separating sulfidic deep waters from oxygenated surface waters, possibly into the photic zone (Fig. 6b). In addition, the presence of free $\mathrm{H}_{2} \mathrm{~S}$ requires nitrate depletion due to the redox potential $\mathrm{O}_{2}>\mathrm{NO}_{3}{ }^{-}>\mathrm{SO}_{4}{ }^{2-}$ (Boyle et al., 2013), which means that instead of denitrification, anammox could have been the dominant process by which fixed-N was removed from the oceanic system, 


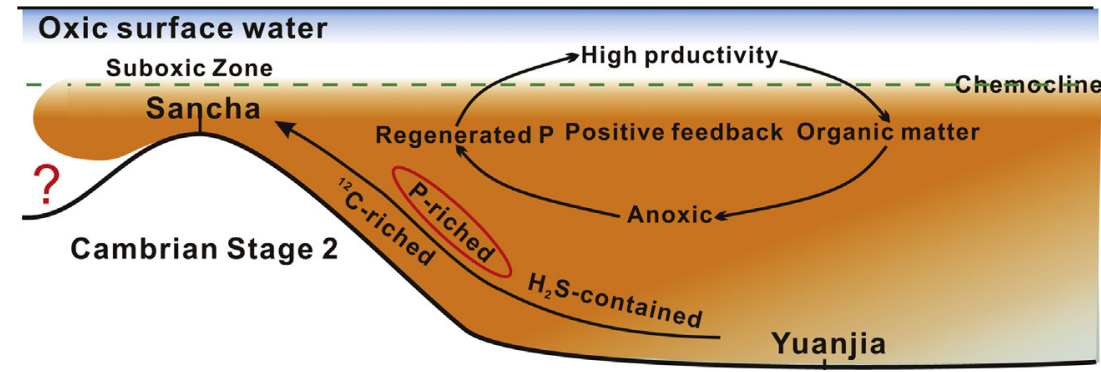

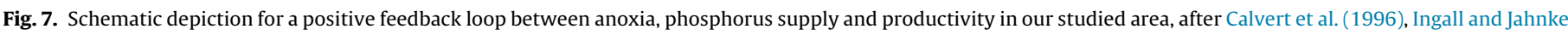
(1994), Ingall and Van Cappellen (1990) and Murphy et al. (2000).

using nitrite as the electron acceptor $\left(\mathrm{NH}_{4}{ }^{+}+\mathrm{NO}_{2}{ }^{-}=\mathrm{N}_{2}+2 \mathrm{H}_{2} \mathrm{O}\right)$ (Kuypers et al., 2003).

\subsubsection{Early Cambrian Stage 3}

During the early Cambrian Stage 3, less anoxic environments have been supported by Fe speciation data from the middle part of the Niutitang (Jiumenchong) Formation in Zhongnan section, Guizhou (Och et al., 2013), Yangjiaping section, Hunan (Feng et al., 2014), Songtao section, Guizhou (Canfield et al., 2008), and Longbizui section, Hunan (Wang et al., 2012a), suggesting dominantly ferruginous conditions, with mid-depth euxinic conditions retreating from the shelf margin to the slope areas, and even occasionally oxic bottom waters in the shelf margin and upper-slope area (Feng et al., 2014; Jin et al., 2014) (Fig. 6c). In Sancha section, moderate $\mathrm{Mo}_{\text {bulk }}$ concentrations and Mo/TOC bulk $_{\text {ratios }}\left([\mathrm{Mo}]_{\text {bulk }}=7-46 \mathrm{ppm}\right.$, $\mathrm{Mo} / \mathrm{TOC}_{\text {bulk }}=8-21$ ) (Fig. 2) indicate non-euxinic to intermittently euxinic environment (Scott and Lyons, 2012), reflecting fluctuated chemocline around the water-sediment interface at the Sancha section (Fig. 6c). For the deep-basinal Yuanjia section, $\mathrm{Mo}_{\text {bulk }}$ concentrations range from 2 to $100 \mathrm{ppm}$ with an average value of $44 \mathrm{ppm}$ (Fig. 2), suggesting at least intermittently euxinic bottom waters (Scott and Lyons, 2012) (Fig. 6c). Low Mo/TOC bulk ratios $(\sim 1-7)$ in the deep-basinal Yuanjia section probably reflect a high degree of deepwater restriction (Algeo and Lyons, 2006; Algeo and Rowe, 2012). During this interval both positive $\delta^{13} \mathrm{C}_{\text {org }}$ and $\delta^{15} \mathrm{~N}_{\text {bulk }}$ excursions occur at the Sancha and Yuanjia sections (Fig. 2). Heavier $\delta^{13} C_{\text {org }}$ values than before are consistent with the deepening of the chemocline and organic synthesis by oxygenic photosynthesis using $\mathrm{CO}_{2}$ in the atmosphere as the dominant process for carbon cycling (Goldberg et al., 2007) (Fig. 6c).

As the chemocline deepened, ammonia would have been quantitatively oxidized to nitrate through nitrification (Fig. 6c). In this case, water-column denitrification and anammox would have resulted in a positive fractionation and a ${ }^{15} \mathrm{~N}$-enriched nitrate pool (Cline and Kaplan, 1975; Liu and Kaplan, 1988) (Fig. 6c). Organisms would have assimilated ${ }^{15} \mathrm{~N}$-enriched nitrate as a bioavailable nitrogen source, leading to the preservation of relatively high $\delta^{15} \mathrm{~N}_{\text {bulk }}$ signals (0-2\%) in the sediments (Fig. 2). However, the $\delta{ }^{15} \mathrm{~N}_{\text {bulk }}$ values (0-2\%) are lower than the average $\delta{ }^{15} \mathrm{~N}_{\text {nitrate }}$ value of modern seawater (+5\%) (Sigman et al., 2009). One possible explanation for this is that the nitrate reservoir of the local basin was small, probably because of intensive loss of nitrate through denitrification, anammox, and reduction by $\mathrm{Fe}^{2+}$ at the redox boundary (Busigny et al., 2013; Hansen et al., 1996; Shen et al., 2013; Straub et al., 1996; Weber et al., 2006a,b) (Fig. 6c), driving $\mathrm{N}_{2-}$ fixation as compensation to lower the $\delta^{15} \mathrm{~N}_{\text {bulk }}$ values toward $0 \%$ 。 (Ader et al., 2014). Another possible explanation is that instead of locally intense $\mathrm{N}_{2}$-fixation, the $\delta^{15} \mathrm{~N}_{\text {bulk }}$ compositions from Sancha and Yuanjia sections at this period could record the $\delta^{15} \mathrm{~N}$ value of the global nitrate reservoir, which was lower than that of the modern ocean. A systematic long-term variation in marine sedimentary $\delta^{15} \mathrm{~N}$ values has been proposed (Algeo et al., 2014), suggesting ${ }^{15} \mathrm{~N}$ depleted isotopic compositions in the Cambrian ocean (Algeo et al., 2014). Low marine sedimentary $\delta^{15} \mathrm{~N}$ values are likely to have been due to enhanced sedimentary denitrification without nitrogen isotopic fractionation effects during greenhouse highstands (Algeo et al., 2014). At the end of this interval, both $\delta^{13} C_{\text {org }}$ and $\delta^{15} \mathrm{~N}_{\text {bulk }}$ decrease back to low values, indicating that the chemocline rose again, along with the reestablishment of anoxia in the basin. One possible reason for the apparent rise of the chemocline could be regression, following the earlier transgression evidenced from the Niutitang (Jiumenchong or Guojiaba) Formation in Yangjiaping section, Hunan, Songtao section, Guizhou, and Shatan section, Sichuan (Feng et al., 2014; Jin et al., 2014). Also the high degree of deepwater restriction was probably controlled by the lower sea level during the regression (Algeo and Rowe, 2012).

\subsubsection{Middle and late Cambrian Stage 3}

In the middle and late parts of Cambrian Stage 3, $\mathrm{Mo}_{\text {bulk }}$ concentrations and $\mathrm{Mo} / \mathrm{TOC}_{\text {bulk }}$ ratios are high (averaging $229 \mathrm{ppm}$ and 18 , respectively) in the Yuanjia section (Fig. 2b), suggesting euxinic environment and more aqueous Mo repletion in the deep watermass than the earlier periods (Algeo and Lyons, 2006; Algeo and Rowe, 2012; Scott and Lyons, 2012) (Fig. 6d). Furthermore, the higher Mo/TOC bulk ratios than those $(\sim 1-14)$ of the Stage 2 transgression imply a larger global Mo reservoir (Algeo and Rowe, 2012; Sahoo et al., 2012; Scott et al., 2008), which could probably mainly be due to more oxygenated open ocean, although enhanced weathering during the Stage 3 regression may also have made contributions. Meanwhile, low $\mathrm{Mo}_{\text {bulk }}$ concentrations and $\mathrm{Mo} / \mathrm{TOC}_{\mathrm{bulk}}$ ratios (averaging $3 \mathrm{ppm}$ and $\sim 8$, respectively) at Sancha section indicate that euxinic conditions did not spread to the shelf marginal regions (Scott and Lyons, 2012) (Fig. 6d). During this time, the $\delta^{15} \mathrm{~N}_{\text {bulk }}$ curve decreases to near $0 \%$ in Sancha section with relatively constant $\delta^{13} C_{\text {org }}$ values (around -30.5\%o), while the $\delta^{15} \mathrm{~N}_{\text {bulk }}$ profile gradually decreases to $-3 \%$ o with an increasing trend for the $\delta^{13} C_{\text {org }}$ curve (from $-33.0 \%$ o to $-31.5 \%$ ) at Yuanjia section (Fig. 2). The low $\delta{ }^{15} \mathrm{~N}_{\text {bulk }}$ values (-3 0\%) could have resulted from ammonia assimilation, representing a shoaling chemocline and euxinic conditions in the photic zone (Fig. $6 \mathrm{~d}$ ). $\delta^{15} \mathrm{~N}_{\text {bulk }}$ values near $0 \%$ at Sancha section indicate that the expanded non-sulfidic anoxia enhanced denitrification and anammox within the redox transition zone, and led to the complete consumption of the bioavailable nitrogen (nitrate and ammonia) in the surface water, making $\mathrm{N}_{2}$ fixation the dominant process (Fig. 6d).

Although Feng et al. (2014) and Jin et al. (2014) have proposed that widespread mid-depth euxinia gradually shrank after the Stage 2 transgression, more details on the marine redox structure evolution during Cambrian Stage 3 are still not clear. Our data suggest that seawater was clearly less anoxic at the beginning of Cambrian Stage 3 than during the transgression, then anoxia expanded again and euxinic conditions were reestablished in the 


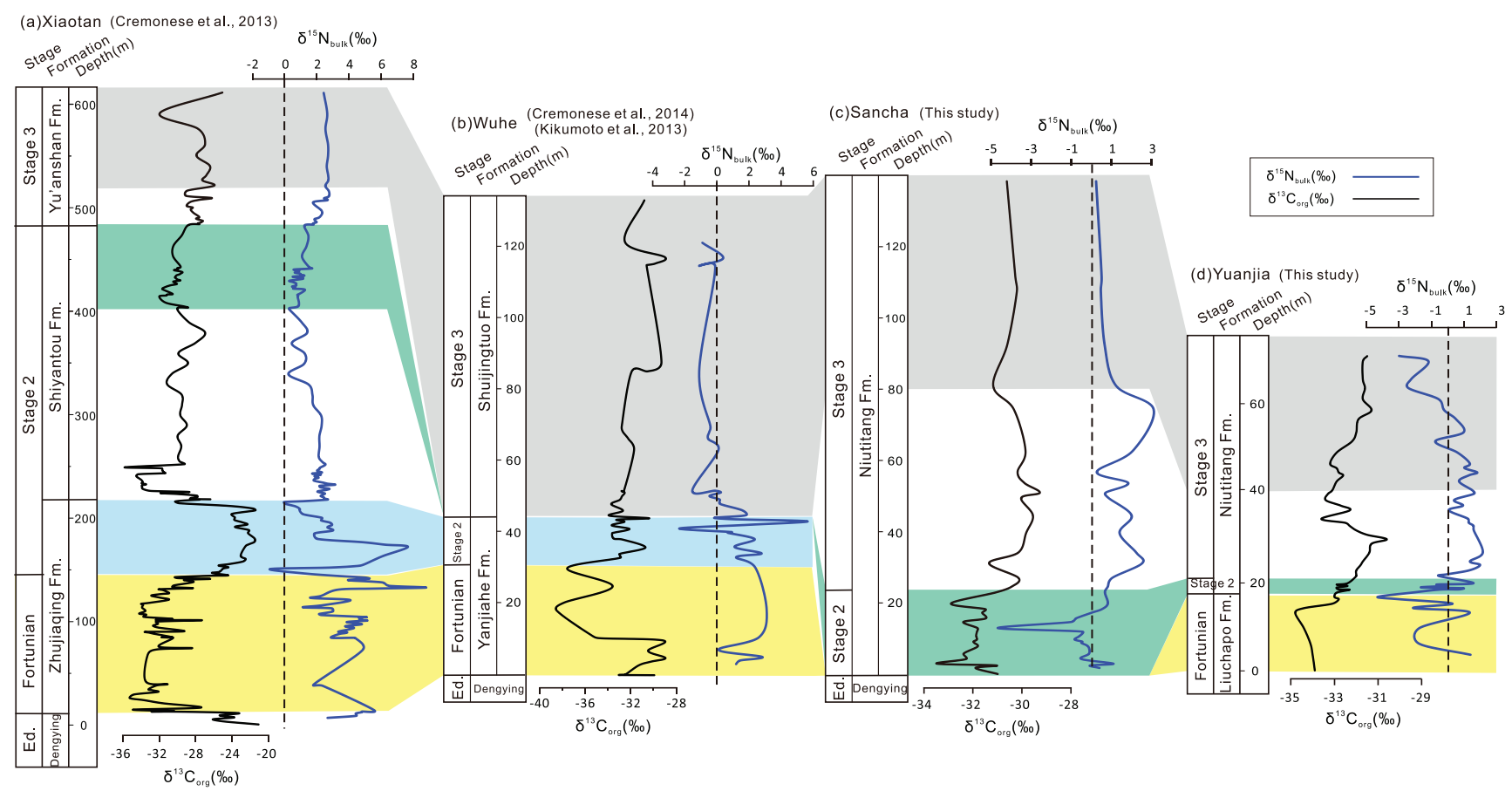

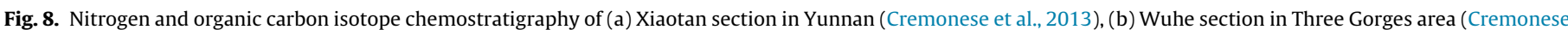
et al., 2014; Kikumoto et al., 2014), and (c) Sancha, (d) Yuanjia sections in Hunan, South China.

slope-basin areas without reaching the shelf margin area in the middle and late Cambrian Stage 3 (Fig. 6b-d). The reduction of euxinic waters in the middle and late Cambrian Stage 3 could be attributed to a decrease in sulfate concentrations induced by previous intensive MSR and pyrite formation. However, the increasing exposure of pyrite-rich sediments during regression would have increased the sulfate flux through weathering into the ocean, enhancing seawater sulfate concentrations (Feng et al., 2014; Jin et al., 2014), and so the reduction of euxinic waters was possibly controlled by organic matter supply. Low TOC $_{\text {bulk }}$ contents of this interval in Sancha section are consistent with this hypothesis. Primary productivity was possibly limited due to the lack of upwelling currents, which caused phosphorus retention in deep anoxic waters. $\delta^{13} C_{\text {org }}$ values at this time are higher than those from Cambrian Stage 2 (Fig. 2), despite evidence for chemocline shoaling into the photic zone during both periods (Fig. $6 \mathrm{~b}$ and d). If this ${ }^{13} \mathrm{C}$-enrichment resulted from a relatively higher proportion of photosynthetic versus chemoautotrophic biomass exporting into the sediments, this could mean that the chemocline was deeper in the photic zone during this interval than during the transgression in the Cambrian Stage 2, although the exact depths are unknown.

\subsection{Paleoenvironment along the southern margin of the Yangtze platform}

The evolution of life in the early Cambrian is closely linked with the ocean chemistry and marine redox structure. To further reconstruct the spatiotemporal variability of marine redox conditions along the southern margin of the Yangtze platform, we correlate $\delta^{15} \mathrm{~N}$ data from this study and published data from Xiaotan section in Yunnan Province (Cremonese et al., 2013) and Wuhe section in the Three Gorges area (Cremonese et al., 2014; Kikumoto et al., 2014), which are located in the shallow platform and transitional zone, respectively (Fig. 8). Stratigraphic correlation is based on the discussion above in Section 5.1.
The Fortunian Stage $\delta^{15} \mathrm{~N}_{\text {bulk }}$ values ranged between $+2 \%$ and $+6 \%$ at Xiaotan section (Fig. 8 a), indicating relatively normal marine productivity conditions on the shallow platform (Cremonese et al., 2013), which could have benefited the bloom of small shelly fossils (SSFs) there. However, in the Three Gorges area, lower $\delta^{15} \mathrm{~N}_{\text {bulk }}$ values between $0 \%$ ond $+3 \%$ c could reflect a stronger contribution from $\mathrm{N}_{2}$-fixation, and that waters in the outer-shelf area were less oxic than the shallow platform during this time interval (Cremonese et al., 2014; Kikumoto et al., 2014) (Fig. 8b). By comparison, the basinal area where Yuanjia strata were deposited was more anoxic with the chemocline in the photic zone, evidenced by variable $\delta^{15} \mathrm{~N}_{\text {bulk }}$ values between $-4.3 \%$ and $+2 \%$ (Fig. 8d).

During early Stage $2, \delta^{15} \mathrm{~N}_{\text {bulk }}$ values fluctuated largely between $-1 \%$ and $+6 \%$ at Xiaotan and Wuhe sections (Fig. $8 \mathrm{a}$ and $\mathrm{b}$ ), indicating changes in the $\mathrm{N}$ cycle between nitrogen fixation and water-column denitrification and/or anammox, which reflects chemocline fluctuations in both the shallow platform and outershelf area (Cremonese et al., 2013, 2014; Kikumoto et al., 2014). For the early Cambrian Stage 2, the $\delta^{15} \mathrm{~N}_{\text {bulk }}$ signal from the shelf margin and basinal areas are not available, owing to the sedimentary hiatus at the Sancha section and very condensed strata in the Yuanjia section, respectively (Jiang et al., 2012; Steiner et al., 2007; Zhu et al., 2003).

During late Stage 2, geographically wide distribution of low $\delta^{15} \mathrm{~N}_{\text {bulk }}$ (Fig. 8) implies that upwelling sulfidic waters led to widespread seawater anoxia in most parts of the basin along the southern margin of the Yangtze Platform, which is consistent with the previous study (Och et al., 2013). This major anoxic event may have resulted in the extinction of many SSF-secreting organisms (Zhu et al., 2006). However, we infer that this was a local anoxic event occurring in this basin while the open ocean was oxygenated to modern-like levels, evidenced by high $\delta^{98}$ Mo values $(\sim+2.4 \%$ o (Chen et al., 2015). $\mathrm{Mo}_{\text {bulk }}$ concentrations and $\mathrm{Mo} / \mathrm{TOC}_{\text {bulk }}$ ratios in the studied sections of this stage are high ([Mo $]_{\text {bulk }}>100 \mathrm{ppm}$, mean $\left.\mathrm{Mo} / \mathrm{TOC}_{\mathrm{bulk}}=\sim 23\right)$. These high concentrations and ratios 


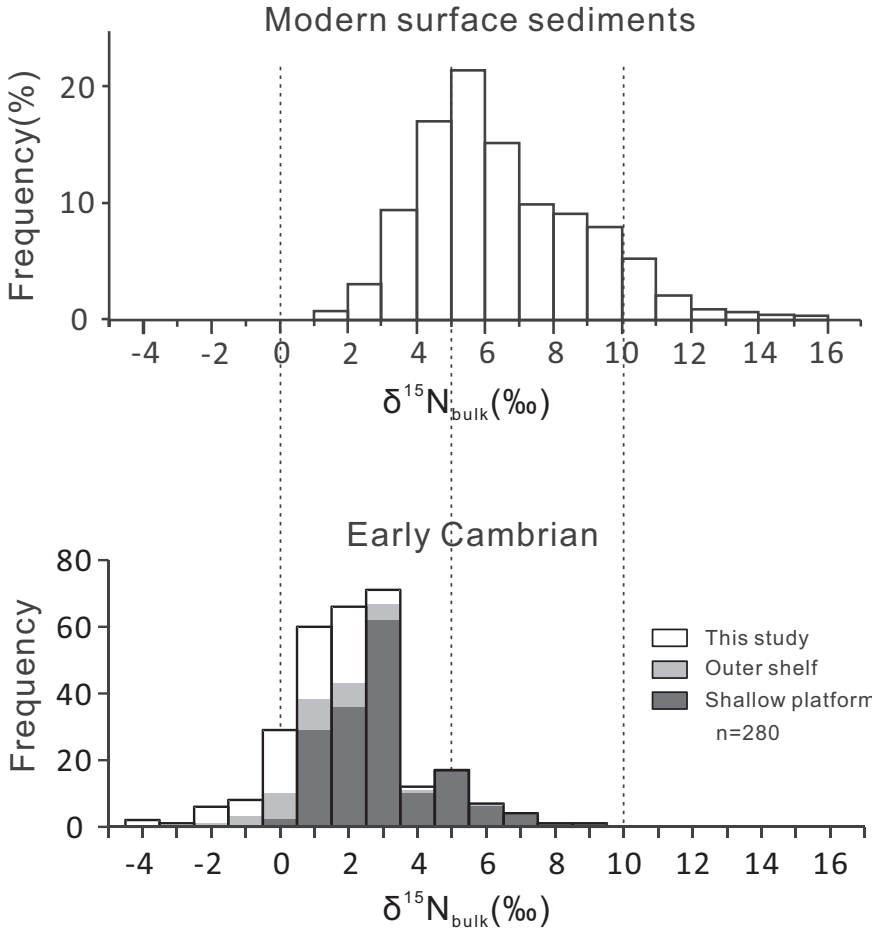

Fig. 9. Nitrogen isotope distributions of modern surface sediments and early Cambrian basin of South China. Modern sediment $\delta^{15} \mathrm{~N}_{\text {bulk }}$ data are from Tesdal et al. (2013), shallow platform $\delta^{15} \mathrm{~N}_{\text {bulk }}$ data are from Cremonese et al. (2013) and outer shelf $\delta^{15} \mathrm{~N}_{\text {bulk }}$ data are from Cremonese et al. (2014) and Kikumoto et al. (2014).

indicate that the shallow waters of the basin were well connected with the oxygenated open ocean and that the open ocean had a large Mo reservoir that could continuously provide abundant Mo into the restricted basin where Mo was efficiently trapped in black shales deposited under euxinic conditions.

In the earliest part of Stage $3, \delta^{15} \mathrm{~N}_{\text {bulk }}$ values in Yunnan and Hunan provinces show positive shifts (2-3\%) (Fig. 8), which suggest seawater oxygenation along most of the whole Yangtze Platform, possibly heralding the explosion of Chengjiang-type fauna. Then combining the low $\delta^{15} \mathrm{~N}_{\text {bulk }}(<0 \%$ ) in deep waters and relatively high $\delta^{15} \mathrm{~N}_{\text {bulk }}(\sim 2-3 \%$ ) in shallow waters into an integrated isotopic and biostratigraphic framework, it is suggested that another anoxic event occurred during middle and late parts of Cambrian Stage 3. However, sulfidic conditions were presented in basinal realms without reaching the shelf margin, while the shallow platform became more oxygenated, accommodating the Chengjiang-type faunas. By this time, the South China basin was well connected with oxygenated open ocean, characterized by a large Mo reservoir as evidenced by high $\mathrm{Mo}_{\text {bulk }}$ concentrations and $\mathrm{Mo} / \mathrm{TOC}_{\text {bulk }}$ ratios ([Mo $]_{\text {bulk }}>100 \mathrm{ppm}$, mean $\mathrm{Mo} / \mathrm{TOC}_{\text {bulk }}=\sim 18$ ) from the Yuanjia section.

On the basis of high $\mathrm{Mo}_{\text {bulk }}$ concentrations and $\mathrm{Mo} / \mathrm{TOC}_{\mathrm{bulk}}$ ratios in the euxinic black shale from this and previous studies (Feng et al., 2014; Guo et al., 2007a), the South China basin was well connected with the open ocean and Mo could be effectively transported into the basin (Algeo and Lyons, 2006; Algeo and Rowe, 2012; Scott and Lyons, 2012). Similarly, nitrate could also be supplied to the basin through surface currents from the open ocean. Therefore, the distribution of $\delta^{15} \mathrm{~N}_{\text {bulk }}$ values from the basin of South China could be representative of the global nitrate reservoir, although $\mathrm{N}$-cycling processes may have modified this locally. The frequency distribution of $\delta^{15} \mathrm{~N}_{\text {bulk }}$ values in the basin was similar to that of the modern ocean (Fig. 9), excepting that most $\delta^{15} \mathrm{~N}_{\text {bulk }}$ values range around $1-3 \%$ and average only $+1.6 \%$, compared with a modern mean seawater $\delta^{15} \mathrm{~N}_{\text {nitrate }}$ value of $+5 \%$ (Sigman et al., 2009) (Fig. 9). In particular, $\delta^{15} \mathrm{~N}_{\text {bulk }}$ data from shallow platform Xiaotan section where the seawater was presumably well oxygenated, mainly range around $+3 \%$ o with a lower mean value of $+2.4 \%$ o as well (Fig. 9 ). These results are consistent with the proposal of a globally ${ }^{15} \mathrm{~N}$ depleted nitrate pool during the Cambrian, resulting from intensive sedimentary denitrification during the greenhouse climates and high sea-levels that were characteristic of this period (Algeo et al., 2014). The negative tail of the distribution $(-5 \sim 0 \%$ ) records the local signal of ammonium assimilation and/or $\mathrm{N}_{2}$-fixation when anoxia expanded into the photic zone (Ader et al., 2014) (Fig. 9).

\section{Summary and conclusions}

The nitrogen isotope composition preserved in sedimentary rocks can record and reflect interactions between the environmental, ecological and biological evolution of the marine paleoenvironment. $\delta^{13} \mathrm{C}_{\text {org }}, \delta^{15} \mathrm{~N}_{\text {bulk }}$, Mo $\mathrm{oulk}_{\text {bul }}$ concentrations and $\mathrm{Mo} / \mathrm{TOC}_{\text {bulk }}$ data were recovered for the early Cambrian shelf margin and deep basin sediments at the southern margin of the Yangtze Platform. Based on these data, a comprehensive understanding of $\mathrm{N}$ cycling and redox evolution in the shelf and basin environment during the early Cambrian has been obtained.

The basinal area adjacent to the Yangtze platform was anoxic during the Cambrian Fortunian Stage, and characterized by a shoaling chemocline that impinged upon the photic zone. The dominant process within the $\mathrm{N}$ cycle shifted at this time between ammonia assimilation and anammox. In the late Cambrian Stage 2, $\mathrm{N}_{2}$ fixation became the dominant process under expanded euxinic condition along with shoaling chemocline possibly into the photic zone in both shelf margin and basinal areas. During the early Cambrian Stage 3, nitrate assimilation came to play an important role, indicating that water stratification was weaker, the nitrate pool was larger, and oxic shallow waters more expanded than before. During the middle and late parts of Cambrian Stage 3, the photic zone became anoxic again, but sulfidic conditions were present only in the basinal area without approaching shelf margin area.

Combining data from this study on sections from the shelf margin to basinal area with data from previous studies of shallow platform sections provides a comprehensive perspective on the spatial variation and temporal evolution of redox conditions in these various marine environments along the southern margin of the Yangtze Platform. Anoxia with intermittent euxinia in the photic zone of the basinal area dominated the interval from the Cambrian Fortunian Stage to Cambrian Stage 3, with the exception of early Stage 3 when an oxygenation event occurred. On the platform, generally oxygenated shallow water was affected only by a major anoxic event during Cambrian Stage 2 . The outer shelf area experienced anoxia from Stage 2 to Stage 3 of the early Cambrian. However, this anoxic event, found only in the South China basin, may have been limited in extent and took place against the backdrop of a global ocean that was highly oxygenated. The South China basin was well connected with the open ocean and so mean low $\delta{ }^{15} \mathrm{~N}_{\text {bulk }}$ values ( $\sim 1.6 \%$ ) probably recorded the ${ }^{15} \mathrm{~N}$-depleted isotopic composition of the global nitrate reservoir in the early Cambrian ocean.

\section{Acknowledgements}

We thank Marianne Falk, Lisa Schlegelmilch and Qian Liu for their assistance with chemical analysis; Prof. Junming Zhang, Dr. Michael Steiner, Dr. Lawrence Och, Dr. Ben Yang, Xi Chen for helpful discussions; Prof. Thomas Algeo and another anonymous reviewer for the helpful suggestions and constructive comments. This study was funded by the National Basic Research Program 
of China (2013CB835004), DFG Forschergruppe 736, and a NSFC program (41230102). Dan Wang was also supported by the China Scholarship Council for her overseas study.

\section{References}

Ader, M., Sansjofre, P., Halverson, G.P., Busigny, V., Trindade, R.I., Kunzmann, M., Nogueira, A.C., 2014. Ocean redox structure across the Late Neoproterozoic Oxygenation Event: a nitrogen isotope perspective. Earth Planet. Sci. Lett. 396, $1-13$.

Algeo, T.J., Lyons, T.W., 2006. Mo-total organic carbon covariation in modern anoxic marine environments: implications for analysis of paleoredox and paleohydrographic conditions. Paleoceanography 21, PA1016.

Algeo, T.J., Maynard, J.B., 2004. Trace-element behavior and redox facies in core shales of Upper Pennsylvanian Kansas-type cyclothems. Chem. Geol. 206, 289-318.

Algeo, T.J., Meyers, P.A., Robinson, R.S., Rowe, H., Jiang, G.Q., 2014. Icehouse-greenhouse variations in marine denitrification. Biogeosciences $11,1273-1295$.

Algeo, T.J., Rowe, H., 2012. Paleoceanographic applications of trace-metal concentration data. Chem. Geol. 324, 6-18.

Altabet, M., 1988. Variations in nitrogen isotopic composition between sinking and suspended particles: implications for nitrogen cycling and particle transformation in the open ocean. Deep Sea Res. Part A. Oceanogr. Res. Pap. 35, 535-554.

Altabet, M.A., Deuser, W.G., Honjo, S., Stienen, C., 1991. Seasonal and depth-related changes in the source of sinking particles in the North-Atlantic. Nature 354, 136-139.

Altabet, M.A., Pilskaln, C., Thunell, R., Pride, C., Sigman, D., Chavez, F., Francois, R., 1999. The nitrogen isotope biogeochemistry of sinking particles from the margin of the Eastern North Pacific. Deep Sea Res. Part I: Oceanogr. Res. Pap. 46, 655-679.

Bahlmann, E., Bernasconi, S.M., Bouillon, S., Houtekamer, M., Korntheuer, M., Langenberg, F., Mayr, C., Metzke, M., Middelburg, J.J., Nagel, B., 2010. Performance evaluation of nitrogen isotope ratio determination in marine and lacustrine sediments: an inter-laboratory comparison. Org. Geochem. 41, 3-12.

Barling, J., Arnold, G.L., Anbar, A.D., 2001. Natural mass-dependent variations in the isotopic composition of molybdenum. Earth Planet. Sci. Lett. 193, 447-457.

Beaumont, V., Robert, F., 1999. Nitrogen isotope ratios of kerogens in Precambrian cherts: a record of the evolution of atmosphere chemistry? Precambrian Res. 96, 63-82.

Bebout, G.E., Fogel, M.L., 1992. Nitrogen-isotope compositions of metasedimentary rocks in the Catalina Schist, California: implications for metamorphic devolatilization history. Geochim. Cosmochim. Acta 56, 2839-2849.

Bertine, K.K., Turekian, K.K., 1973. Molybdenum in marine deposits. Geochim. Cosmochim. Acta 37, 1415-1434.

Boyle, R., Clark, J., Poulton, S., Shields-Zhou, G., Canfield, D., Lenton, T., 2013. Nitrogen cycle feedbacks as a control on euxinia in the mid-Proterozoic ocean. Nat. Commun. 4, 1533.

Busigny, V., Lebeau, O., Ader, M., Krapež, B., Bekker, A., 2013. Nitrogen cycle in the Late Archean ferruginous ocean. Chem. Geol. 362, 115-130.

Calvert, S., 2004. Beware intercepts: interpreting compositional ratios in multicomponent sediments and sedimentary rocks. Org. Geochem. 35, 981-987.

Calvert, S., Bustin, R., Ingall, E., 1996. Influence of water column anoxia and sediment supply on the burial and preservation of organic carbon in marine shales. Geochim. Cosmochim. Acta 60,1577-1593.

Canfield, D.E., Glazer, A.N., Falkowski, P.G., 2010. The evolution and future of Earth's nitrogen cycle. Science 330, 192-196.

Canfield, D.E., Poulton, S.W., Knoll, A.H., Narbonne, G.M., Ross, G., Goldberg, T., Strauss, H., 2008. Ferruginous conditions dominated later Neoproterozoic deepwater chemistry. Science 321, 949-952.

Canfield, D.E., Poulton, S.W., Narbonne, G.M., 2007. Late-Neoproterozoic deep-ocean oxygenation and the rise of animal life. Science 315, 92-95.

Chen, X., Ling, H.-F., Vance, D., Shields-Zhou, G.A., Zhu, M., Poulton, S.W., Och, L.M., Jiang, S.-Y., Li, D., Cremonese, L., Archer, C., 2015. Rise to modern levels of ocean oxygenation coincided with the Cambrian radiation of animals. Nat. Commun.,

Cline, J., Kaplan, I., 1975. Isotopic fractionation of dissolved nitrate during denitrification in the eastern tropical North Pacific Ocean. Mar. Chem. 3, 271-299.

Collier, R.W., 1985. Molybdenum in the Northeast Pacific Ocean. Limnol. Oceanogr. 30, 1351-1354.

Compston, W., Zhang, Z., Cooper, J.A., Ma, G., Jenkins, R.J.F., 2008. Further SHRIMP geochronology on the early Cambrian of South China. Am. J. Sci. 308, 399-420.

Cremonese, L., Shields-Zhou, G., Struck, U., Ling, H.F., Och, L., Chen, X., Li, D., 2013. Marine biogeochemical cycling during the early Cambrian constrained by a nitrogen and organic carbon isotope study of the Xiaotan section, South China. Precambrian Res. 225, 148-165.

Cremonese, L., Shields-Zhou, G.A., Struck, U., Ling, H.-F., Och, L.M., 2014. Nitrogen and organic carbon isotope stratigraphy of the Yangtze Platform during the Ediacaran-Cambrian transition in South China. Palaeogeogr. Palaeoclimatol. Palaeoecol. 398, 165-186.

Crowe, S.A., Fowle, D.A., Katsev, S., Sundby, B., Mucci, A., Haffner, G.D., 2008a. Geochemistry of Mo in a modern Archean ocean analogue. Geochim. Cosmochim. Acta 72, A190-A190.
Crowe, S.A., Jones, C., Katsev, S., Magen, C., O'Neill, A.H., Sturm, A., Canfield, D.E. Haffner, G.D., Mucci, A., Sundby, B., Fowle, D.A., 2008b. Photoferrotrophs thrive in an Archean Ocean analogue. Proc. Natl. Acad. Sci. U. S. A. 105, 15938-15943.

Crowe, S.A., Katsev, S., Leslie, K., Sturm, A., Magen, C., Nomosatryo, S., Pack, M.A Kessler, J.D., Reeburgh, W.S., Roberts, J.A., GonzÁLez, L., Douglas Haffner, G., Mucci, A., Sundby, B., Fowle, D.A., 2011. The methane cycle in ferruginous Lake Matano. Geobiology 9, 61-78.

Dahl, T.W., Canfield, D.E., Rosing, M.T., Frei, R.E., Gordon, G.W., Knoll, A.H., Anbar, A.D. 2011. Molybdenum evidence for expansive sulfidic water masses in $\sim 750 \mathrm{Ma}$ oceans. Earth Planet. Sci. Lett. 311, 264-274.

Emerson, S.R., Huested, S.S., 1991. Ocean anoxia and the concentrations of molybdenum and vanadium in seawater. Mar. Chem. 34, 177-196.

Erickson, B.E., Helz, G.R., 2000. Molybdenum(VI) speciation in sulfidic waters: stability and lability of thiomolybdates. Geochim. Cosmochim. Acta 64, 1149-1158.

Feng, L., Li, C., Huang, J., Chang, H., Chu, X., 2014. A sulfate control on marine middepth euxinia on the early Cambrian (ca. 529-521 Ma) Yangtze platform, South China. Precambrian Res. 246, 123-133.

Fike, D., Grotzinger, J., Pratt, L., Summons, R., 2006. Oxidation of the Ediacaran ocean. Nature 444, 744-747.

Freudenthal, T., Wagner, T., Wenzhöfer, F., Zabel, M., Wefer, G., 2001. Early diagenesis of organic matter from sediments of the eastern subtropical Atlantic: evidence from stable nitrogen and carbon isotopes. Geochim. Cosmochim. Acta 65, 1795-1808.

Fry, B., Jannasch, H.W., Molyneaux, S.J., Wirsen, C.O., Muramoto, J.A., King, S., 1991 Stable isotope studies of the carbon, nitrogen and sulfur cycles in the Black Sea and the Cariaco Trench. Deep Sea Res. Part A: Oceanogr. Res. Pap. 38 (Supplement 2), S1003-S1019.

Garvin, J., Buick, R., Anbar, A.D., Arnold, G.L., Kaufman, A.J., 2009. Isotopic evidence for an aerobic nitrogen cycle in the latest Archean. Science 323, 1045-1048.

Gaye, B., Wiesner, M., Lahajnar, N., 2009. Nitrogen sources in the South China Sea, as discerned from stable nitrogen isotopic ratios in rivers, sinking particles, and sediments. Mar. Chem. 114, 72-85.

Godfrey, L.V., Glass, J.B., 2010. The geochemical record of the ancient nitrogen cycle nitrogen isotopes, and metal cofactors. Methods Enzymol. 486, 483-506.

Goldberg, T., Archer, C., Vance, D., Poulton, S.W., 2009. Mo isotope fractionation during adsorption to Fe (oxyhydr) oxides. Geochim. Cosmochim. Acta 73, 6502-6516.

Goldberg, T., Gordon, G., Izon, G., Archer, C., Pearce, C.R., McManus, J., Anbar, A.D. Rehkämper, M., 2013. Resolution of inter-laboratory discrepancies in Mo isotope data: an intercalibration. J. Anal. At. Spectrom. 28, 724-735.

Goldberg, T., Poulton, S.W., Strauss, H., 2005. Sulphur and oxygen isotope signatures of late Neoproterozoic to early Cambrian sulphate, Yangtze Platform, China: diagenetic constraints and seawater evolution. Precambrian Res. 137, 223-241.

Goldberg, T., Strauss, H., Guo, Q.J., Liu, C.Q., 2007. Reconstructing marine redox conditions for the early Cambrian Yangtze Platform: evidence from biogenic sulphur and organic carbon isotopes. Palaeogeogr. Palaeoclimatol. Palaeoecol. 254, 175-193.

Guo, J.F., Li, Y., Li, G.X., 2014. Small shelly fossils from the early Cambrian Yanjiahe Formation, Yichang, Hubei, China. Gondwana Res. 25, 999-1007.

Guo, Q., Deng, D., et al., 2015. Ocean Margin Oxygenation Across the Early Cambrian Transition as a Trigger for the "Cambrian Explosion" (submitted for publication).

Guo, Q Shields, G.A., Liu, C., Strauss, H., Zhu, M., Pi, D., Goldberg T., Yang, X, 2007a. Trace element chemostratigraphy of two Ediacaran-Cambrian successions in South China: implications for organosedimentary metal enrichment and silicification in the Early Cambrian. Palaeogeogr. Palaeoclimatol. Palaeoecol. 254, 194-216.

Guo, Q., Strauss, H., Zhu, M., Zhang, J., Yang, X., Lu, M., Zhao, F., 2013. High resolution organic carbon isotope stratigraphy from a slope to basinal setting on the Yangtze Platform, South China: implications for the Ediacaran-Cambrian transition. Precambrian Res. 225, 209-217.

Guo, Q.J., Strauss, H., Liu, C.Q., Goldberg, T., Zhu, M.Y., Pi, D.H., Heubeck, C., Vemhet, E., Yang, X.L., Fu, P.Q., 2007b. Carbon isotopic evolution of the terminal neoproterozoic and early Cambrian: evidence from the Yangtze platform, South China. Palaeogeogr. Palaeoclimatol. Palaeoecol. 254, 140-157.

Hansen, H.C.B., Koch, C.B., Nancke-Krogh, H., Borggaard, O.K., Sørensen, J., 1996. Abiotic nitrate reduction to ammonium: key role of green rust. Environ. Sci. Technol. 30, 2053-2056.

Hayes, J.M., Wedeking, K.W., Kaplan, I.R., 1983. Precambrian Organic Geochemistry - Preservation of the Record.

Helz, G.R., Bura-Nakic, E., Mikac, N., Ciglenecki, I., 2011. New model for molybdenum behavior in euxinic waters. Chem. Geol. 284, 323-332.

Helz, G.R., Miller, C.V., Charnock, J.M., Mosselmans, J.F.W., Pattrick, R.A.D., Garner C.D., Vaughan, D.J., 1996. Mechanism of molybdenum removal from the sea and its concentration in black shales: EXAFS evidence. Geochim. Cosmochim. Acta 60, 3631-3642

Higgins, M.B., Robinson, R.S., Carter, S.J., Pearson, A., 2010. Evidence from chlorin nitrogen isotopes for alternating nutrient regimes in the Eastern Mediterranean Sea. Earth Planet. Sci. Lett. 290, 102-107.

Higgins, M.B., Robinson, R.S., Husson, J.M., Carter, S.J., Pearson, A., 2012. Dominant eukaryotic export production during ocean anoxic events reflects the importance of recycled $\mathrm{NH}^{4+}$. Proc. Natl. Acad. Sci. 109, 2269-2274.

Holland, H.D., 1984. The Chemical Evolution of the Atmosphere and Oceans. Princeton University Press.

Huerta-Diaz, M.A., Morse, J.W., 1992. Pyritization of trace-metals in anoxic marinesediments. Geochim. Cosmochim. Acta 56, 2681-2702. 
Ingall, E., Jahnke, R., 1994. Evidence for enhanced phosphorus regeneration from marine sediments overlain by oxygen depleted waters. Geochim. Cosmochim. Acta 58, 2571-2575.

Ingall, E.D., Bustin, R.M., Van Cappellen, P., 1993. Influence of water column anoxia on the burial and preservation of carbon and phosphorus in marine shales. Geochim. Cosmochim. Acta 57, 303-316.

Ingall, E.D., Van Cappellen, P., 1990. Relation between sedimentation-rate and burial of organic phosphorus and organic-carbon in marine-sediments. Geochim. Cosmochim. Acta 54, 373-386.

Ishikawa, T., Ueno, Y., Komiya, T., Sawaki, Y., Han, J., Shu, D.G., Li, Y., Maruyama, S., Yoshida, N., 2008. Carbon isotope chemostratigraphy of a Precambrian/Cambrian boundary section in the Three Gorge area, South China: prominent global-scale isotope excursions just before the Cambrian Explosion. Gondwana Res. 14, 193-208.

Jenkyns, H.C., Gröcke, D.R., Hesselbo, S.P., 2001. Nitrogen isotope evidence for water mass denitrification during the early Toarcian (Jurassic) oceanic anoxic event Paleoceanography 16, 593-603.

Jia, Y., 2006. Nitrogen isotope fractionations during progressive metamorphism: a case study from the Paleozoic Cooma metasedimentary complex, southeastern Australia. Geochim. Cosmochim. Acta 70, 5201-5214.

Jiang, G.Q., Wang, X.Q., Shi, X.Y., Xiao, S.H., Zhang, S.H., Dong, J., 2012. The origin of decoupled carbonate and organic carbon isotope signatures in the early Cambrian (ca. 542-520 Ma) Yangtze platform. Earth Planet. Sci. Lett. 317, 96-110.

Jiang, G.Q., Shi, X.Y., Zhang, S.H., Wang, Y., Xiao, S.H., 2011. Stratigraphy and paleogeography of the Ediacaran Doushantuo Formation (ca. 635-551 Ma) in South China. Gondwana Res. 19, 831-849.

Jiang, S.-Y., Chen, Y.-Q., Ling, H.-F., Yang, J.-H., Feng, H.-Z., Ni, P., 2006. Trace-and rareearth element geochemistry and $\mathrm{Pb}-\mathrm{Pb}$ dating of black shales and intercalated Ni-Mo-PGE-Au sulfide ores in Lower Cambrian strata, Yangtze Platform, South China. Miner. Depos. 41, 453-467.

Jiang, S.-Y., Pi, D.-H., Heubeck, C., Frimmel, H., Liu, Y.-P., Deng, H.-L., Ling, H.-F., Yang, J.-H., 2009. Early Cambrian ocean anoxia in south China. Nature 459, E5-E6.

Jiang, S.-Y., Yang, J.-H., Ling, H.-F., Chen, Y.-Q., Feng, H.-Z., Zhao, K.-D., Ni, P., 2007. Extreme enrichment of polymetallic Ni-Mo-PGE-Au in Lower Cambrian black shales of South China: an Os isotope and PGE geochemical investigation. Palaeogeogr. Palaeoclimatol. Palaeoecol. 254, 217-228.

Jin, C.S., Li, C., Peng, X.F., Cui, H., Shi, W., Zhang, Z.H., Luo, G.M., Xie, S.C., 2014. Spatiotemporal variability of ocean chemistry in the early Cambrian, South China. Sci. China Earth Sci. 57, 579-591.

Junium, C.K., Arthur, M.A., 2007. Nitrogen cycling during the Cretaceous, Cenomanian-Turonian oceanic anoxic event II. Geochem. Geophys. Geosyst. 8 Q03002.

Küspert, W., 1982. Environmental changes during oil shale deposition as deduced from stable isotope ratios. In: Einsele, G., Seilacher, A. (Eds.), Cyclic and Event Stratification. Springer, Berlin Heidelberg, pp. 482-501.

Kappler, A., Pasquero, C., Konhauser, K.O., Newman, D.K., 2005. Deposition of banded iron formations by anoxygenic phototrophic Fe(II)-oxidizing bacteria. Geology 33, 865-868.

Kikumoto, R., Tahata, M., Nishizawa, M., Sawaki, Y., Maruyama, S., Shu, D.G., Han, J. Komiya, T., Takai, K., Ueno, Y., 2014. Nitrogen isotope chemostratigraphy of the Ediacaran and Early Cambrian platform sequence at Three Gorges, South China. Gondwana Res. 25, 1057-1069.

Kimura, H., Watanabe, Y., 2001. Oceanic anoxia at the Precambrian-Cambrian boundary. Geology 29, 995-998.

Kuypers, M.M., Sliekers, A.O., Lavik, G., Schmid, M., Jørgensen, B.B., Kuenen, J.G., Damsté, J.S.S., Strous, M., Jetten, M.S., 2003. Anaerobic ammonium oxidation by anammox bacteria in the Black Sea. Nature 422, 608-611.

Lehmann, B., Nägler, T.F., Holland, H.D., Wille, M., Mao, J., Pan, J., Ma, D., Dulski, P., 2007. Highly metalliferous carbonaceous shale and Early Cambrian seawater. Geology 35, 403-406

Lehmann, M.F., Bernasconi, S.M., Barbieri, A., McKenzie, J.A., 2002. Preservation of organic matter and alteration of its carbon and nitrogen isotope composition during simulated and in situ early sedimentary diagenesis. Geochim. Cosmochim. Acta 66, 3573-3584.

Lehmann, M.F., Reichert, P., Bernasconi, S.M., Barbieri, A., McKenzie, J.A., 2003. Modelling nitrogen and oxygen isotope fractionation during denitrification in lacustrine redox-transition zone. Geochim. Cosmochim. Acta 67, 2529-2542.

Li, C., Love, G.D., Lyons, T.W., Fike, D.A., Sessions, A.L., Chu, X., 2010. A stratified redox model for the Ediacaran ocean. Science 328, 80-83.

Li, C., Love, G.D., Lyons, T.W., Scott, C.T., Feng, L., Huang, J., Chang, H., Zhang, Q., Chu, X., 2012a. Evidence for a redox stratified Cryogenian marine basin, Datangpo Formation, South China. Earth Planet. Sci. Lett. 331-332, 246-256.

Li, D., Ling, H.-F., Shields-Zhou, G.A., Chen, X., Cremonese, L., Och, L., Thirlwall, M., Manning, C.J., 2013a. Carbon and strontium isotope evolution of seawater across the Ediacaran-Cambrian transition: evidence from the Xiaotan section, NE Yunnan, South China. Precambrian Res. 225, 128-147.

Li, G., Xiao, S., 2004. Tannuolina and Micrina (Tannuolinidae) from the Lower Cambrian of eastern Yunnan, South China, and their scleritome reconstruction. Paleontol. 78, 900-913.

Li, M.-C., Ding, H., Jiao, K., Yao, S.-P., 2012b. Organic petrology of Niutitang Formation in Shancha, western Hunan Province, China. Nat. Gas Geosci. 23, 1077-1089 (In Chinese with English abstract).

Li, M.-C., Yao, S.-P., Ding, H., Wu, H., Tang, Z.-Y., Hu, K., 2013b. Geochemistry, paleontology and sedimentary environment significance of Niutitang Formation in Western Hunan Province of China. J. China Coal Soc. 38, 857-863 (In Chinese with English abstract).
Li, Z.X., Zhang, L., Powell, C.M., 1996. Positions of the East Asian cratons in the Neoproterozoic supercontinent Rodinia. Aust. J. Earth Sci. 43, 593-604.

Liu, K.-K., Kaplan, I.R., 1988. Variation of nitrogen isotope fractionation during denitrification and nitrogen isotope balance in the ocean. Chem. Geol. 70, 196.

Lott, D., Coveney, R., Murowchick, J., Grauch, R., 1999. Sedimentary exhalative nickelmolybdenum ores in South China. Econ. Geol. 94, 1051-1066.

Luo, G., Wang, Y., Algeo, T.J., Kump, L.R., Bai, X., Yang, H., Yao, L., Xie, S., 2011 Enhanced nitrogen fixation in the immediate aftermath of the latest Permian marine mass extinction. Geology 39, 647-650.

Lyons, T.W., Anbar, A.D., Severmann, S., Scott, C., Gill, B.C., 2009. Tracking euxinia in the ancient ocean: a multiproxy perspective and Proterozoic case study. Annu. Rev. Earth Planet. Sci. 37, 507-534.

Lyons, T.W., Reinhard, C.T., Love, G.D., Xiao, S., 2012. Geobiology of the Proterozoic Eon, Fundamentals of Geobiology. John Wiley \& Sons, Ltd, pp. 371-402.

Möbius, J., 2013. Isotope fractionation during nitrogen remineralization (ammonification): implications for nitrogen isotope biogeochemistry. Geochim. Cosmochim. Acta 105, 422-432

Möbius, J., Gaye, B., Lahajnar, N., Bahlmann, E., Emeis, K.-C., 2011. Influence of diagenesis on sedimentary $\delta^{15} \mathrm{~N}$ in the Arabian Sea over the last $130 \mathrm{kyr}$. Mar. Geol. 284, 127-138.

Möbius, J., Lahajnar, N., Emeis, K.-C., 2010. Diagenetic control of nitrogen isotope ratios in Holocene sapropels and recent sediments from the Eastern Mediterranean Sea. Biogeosci. Discuss. 7, 1131-1165.

Macko, S.A., Estep, M.L.F., Engel, M.H., Hare, P.E., 1986. Kinetic fractionation of stable nitrogen isotopes during amino acid transamination. Geochim. Cosmochim. Acta $50,2143-2146$.

Mao, J., Lehmann, B., Du, A., Zhang, G., Ma, D., Wang, Y., Zeng, M., Kerrich, R., 2002 Re-Os dating of polymetallic Ni-Mo-PGE-Au mineralization in Lower Cambrian black shales of South China and its geologic significance. Econ. Geol. 97, 1051-1061.

McManus, J., Berelson, W.M., Severmann, S., Poulson, R.L., Hammond, D.E., Klinkhammer, G.P., Holm, C., 2006. Molybdenum and uranium geochemistry in continental margin sediments: paleoproxy potential. Geochim. Cosmochim. Acta 70, 4643-4662.

McManus, J., Nägler, T.F., Siebert, C., Wheat, C.G., Hammond, D.E., 2002. Oceanic molybdenum isotope fractionation: diagenesis and hydrothermal ridge-flank alteration. Geochem. Geophys. Geosyst. 3, 1-9.

Mingram, B., Bräuer, K., 2001. Ammonium concentration and nitrogen isotope composition in metasedimentary rocks from different tectonometamorphic units of the European Variscan Belt. Geochim. Cosmochim. Acta 65, 273-287.

Morford, J.L., Emerson, S., 1999. The geochemistry of redox sensitive trace metals in sediments. Geochim. Cosmochim. Acta 63, 1735-1750.

Murphy, A.E., Sageman, B.B., Hollander, D.J., 2000. Eutrophication by decoupling of the marine biogeochemical cycles of $\mathrm{C}, \mathrm{N}$, and $\mathrm{P}$ : a mechanism for the Late Devonian mass extinction. Geology 28, 427-430.

Nakanishi, T., Minagawa, M., 2003. Stable carbon and nitrogen isotopic compositions of sinking particles in the northeast Japan Sea. Geochem. J. 37, 261-276.

Nguyen, R.T., Harvey, H.R., 1997. Protein and amino acid cycling during phytoplankton decomposition in oxic and anoxic waters. Org. Geochem. 27, 115-128.

Och, L.M., 2011. Biogeochemical Cycling Through the Neoproterozoic-Cambrian Transition in China: An Integrated Study of Redox-Sensitive Elements. UCL (University College London).

Och, L.M., Shields-Zhou, G.A., Poulton, S.W., Manning, C., Thirlwall, M.F., Li, D., Chen, X., Ling, H., Osborn, T., Cremonese, L., 2013. Redox changes in Early Cambrian black shales at Xiaotan section, Yunnan Province, South China. Precambrian Res. 225, 166-189.

Ohkouchi, N., Nakajima, Y., Okada, H., Ogawa, N.O., Suga, H., Oguri, K., Kitazato, H., 2005. Biogeochemical processes in the saline meromictic Lake Kaiike, Japan: implications from molecular isotopic evidences of photosynthetic pigments. Environ. Microbiol. 7, 1009-1016.

Papineau, D., Purohit, R., Goldberg, T., Pi, D., Shields, G.A., Bhu, H., Steele, A., Fogel, M.L., 2009. High primary productivity and nitrogen cycling after the Paleoproterozoic phosphogenic event in the Aravalli Supergroup, India. Precambrian Res. 171, 37-56.

Pašava, J., Kř́ibek, B., Vymazalova, A., Sýkorová, I., Žák, K., Orberger, B., 2008. Multiple sources of metals of mineralization in Lower Cambrian black shales of South China: evidence from geochemical and petrographic study. Resour. Geol. 58, 25-42.

Pennock, J.R., Velinsky, D.J., Ludlam, J.M., Sharp, J.H., Fogel, M.L., 1996. Isotopic fractionation of ammonium and nitrate during uptake by Skeletonema costatum: implications for $\delta^{15} \mathrm{~N}$ dynamics under bloom conditions. Limnol. Oceanogr. 41 451-459.

Pinti, D.L., Hashizume, K., 2011. Early Life Record from Nitrogen Isotopes. Earliest Life on Earth: Habitats, Environments and Methods of Detection. Springer, pp. $183-205$.

Pinti, D.L., Hashizume, K., Orberger, B., Gallien, J.P., Cloquet, C., Massault, M., 2007 Biogenic nitrogen and carbon in Fe-Mn-oxyhydroxides from an Archean chert, Marble Bar, Western Australia. Geochem. Geophys. Geosyst. 8, Q02007.

Poulton, S.W., Canfield, D.E., 2011. Ferruginous conditions: a dominant feature of the ocean through earth's history. Elements 7, 107-112.

Poulton, S.W., Fralick, P.W., Canfield, D.E., 2010. Spatial variability in oceanic redox structure 1.8 billion years ago. Nat. Geosci. 3, 486-490.

Prokopenko, M., Hammond, D., Berelson, W., Bernhard, J., Stott, L., Douglas, R., 2006 Nitrogen cycling in the sediments of Santa Barbara basin and Eastern Subtropical North Pacific: nitrogen isotopes, diagenesis and possible chemosymbiosis 
between two lithotrophs (Thioploca and Anammox) - "riding on a glider". Earth Planet. Sci. Lett. 242, 186-204.

Redfield, A.C., 1963. The influence of organisms on the composition of sea water. Sea, 26-77.

Reinhard, C.T., Raiswell, R., Scott, C., Anbar, A.D., Lyons, T.W., 2009. A late Archean sulfidic sea stimulated by early oxidative weathering of the continents. Science 326, 713-716.

Robinson, R.S., Kienast, M., Luiza Albuquerque, A., Altabet, M., Contreras, S., De Pol Holz, R., Dubois, N., Francois, R., Galbraith, E., Hsu, T.-C., Ivanochko, T., Jaccard, S., Kao, S.-J., Kiefer, T., Kienast, S., Lehmann, M., Martinez, P., McCarthy, M., Möbius, J., Pedersen, T., Quan, T.M., Ryabenko, E., Schmittner, A., Schneider, R. Schneider-Mor, A., Shigemitsu, M., Sinclair, D., Somes, C., Studer, A., Thunell, R., Yang, J.-Y., 2012. A review of nitrogen isotopic alteration in marine sediments. Paleoceanography 27, PA4203.

Robl, T.L., Barron, L.S., 1988. The geochemistry of Devonian black shales in central Kentucky and its relationship to inter-basinal correlation and depositional environment. In: Devonian of the World: Proceedings of the 2nd International Symposium on the Devonian System - Memoir 14, volume II: Sedimentation, pp. 377-392.

Sahoo, S.K., Planavsky, N.J., Kendall, B., Wang, X., Shi, X., Scott, C., Anbar, A.D., Lyons, T.W., Jiang, G., 2012. Ocean oxygenation in the wake of the Marinoan glaciation. Nature 489, 546-549.

Schouten, S., Van Kaam-Peters, H.M., Rijpstra, W.I.C., Schoell, M., Damste, J.S.S., 2000. Effects of an oceanic anoxic event on the stable carbon isotopic composition of early Toarcian carbon. Am. J. Sci. 300, 1-22

Schütter, S.R., 1998. Characteristics of shale deposition in relation to stratigraphic system tracts. Shales Mudstones, 79-108.

Scott, C., Lyons, T., Bekker, A., Shen, Y., Poulton, S., Chu, X., Anbar, A., 2008. Tracing the stepwise oxygenation of the Proterozoic ocean. Nature 452, 456-459.

Scott, C., Lyons, T.W., 2012. Contrasting molybdenum cycling and isotopic properties in euxinic versus non-euxinic sediments and sedimentary rocks: refining the paleoproxies. Chem. Geol. 324, 19-27.

Shen, Y., Pinti, D.L., Hashizume, K., 2013. Biogeochemical Cycles of Sulfur and Nitrogen in the Archean Ocean and Atmosphere. Geophysical Monograph Series. American Geophysical Union, pp. 305-320.

Siebert, C., Nägler, T.F., von Blanckenburg, F., Kramers, J.D., 2003. Molybdenum isotope records as a potential new proxy for paleoceanography. Earth Planet. Sci. Lett. 211, 159-171.

Sigman, D., Karsh, K., Casciotti, K., 2009. Ocean Process Tracers: Nitrogen Isotopes in the Ocean. Encyclopedia of Ocean Science, 2nd ed. Elsevier, Amsterdam.

Steiner, M., Li, G., Qian, Y., Zhu, M., Erdtmann, B.-D., 2007. Neoproterozoic to early Cambrian small shelly fossil assemblages and a revised biostratigraphic correlation of the Yangtze Platform (China). Palaeogeogr. Palaeoclimatol. Palaeoecol. 254, 67-99.

Steiner, M., Wallis, E., Erdtmann, B.D., Zhao, Y.L., Yang, R.D., 2001. Submarinehydrothermal exhalative ore layers in black shales from South China and associated fossils - insights into a Lower Cambrian facies and bio-evolution. Palaeogeogr. Palaeoclimatol. Palaeoecol. 169, 165-191.

Steiner, M., Zhu, M., Zhao, Y., Erdtmann, B.-D., 2005. Lower Cambrian burgess shaletype fossil associations of south China. Palaeogeogr. Palaeoclimatol. Palaeoecol. 220, 129-152.

Straub, K.L., Benz, M., Schink, B., Widdel, F., 1996. Anaerobic, nitrate-dependent microbial oxidation of ferrous iron. Appl. Environ. Microbiol. 62, 1458-1460.

Struck, U., Emeis, K.-C., Voß, M., Krom, M.D., Rau, G.H., 2001. Biological productivity during sapropel S5 formation in the Eastern Mediterranean Sea: evidence from stable isotopes of nitrogen and carbon. Geochim. Cosmochim. Acta 65, 3249-3266.

Tesdal, J.-E., Galbraith, E., Kienast, M., 2013. Nitrogen isotopes in bulk marine sediment: linking seafloor observations with subseafloor records. Biogeosciences 10, 101-118.

Thomazo, C., Ader, M., Philippot, P., 2011. Extreme ${ }^{15} \mathrm{~N}$-enrichments in 2.72-Gyrold sediments: evidence for a turning point in the nitrogen cycle. Geobiology 9 , 107-120.

Tribovillard, N., Algeo, T.J., Lyons, T., Riboulleau, A., 2006. Trace metals as paleoredox and paleoproductivity proxies: an update. Chem. Geol. 232, 12-32.

Tribovillard, N., Riboulleau, A., Lyons, T., Baudin, F.O., 2004. Enhanced trapping of molybdenum by sulfurized marine organic matter of marine origin in Mesozoic limestones and shales. Chem. Geol. 213, 385-401.
Tyrrell, T., 1999. The relative influences of nitrogen and phosphorus on oceanic primary production. Nature 400, 525-531.

Van Cappellen, P., Ingall, E.D., 1994. Benthic phosphorus regeneration, net primary production, and ocean anoxia: a model of the coupled marine biogeochemica cycles of carbon and phosphorus. Paleoceanography 9, 677-692.

Velinsky, D.J., Fogel, M.L., 1999. Cycling of dissolved and particulate nitrogen and carbon in the Framvaren Fjord, Norway: stable isotopic variations. Mar. Chem. 67, 161-180

Vernhet, E., 2007. Paleobathymetric influence on the development of the late Ediacaran Yangtze platform (Hubei, Hunan, and Guizhou provinces, China). Sediment. Geol. 197, 29-46.

Vorlicek, T.P., Helz, G.R., 2002. Catalysis by mineral surfaces: implications for Mo geochemistry in anoxic environments. Geochim. Cosmochim. Acta 66, 36793692.

Vorlicek, T.P., Kahn, M.D., Kasuya, Y., Helz, G.R., 2004. Capture of molybdenum in pyrite-forming sediments: role of ligand-induced reduction by polysulfides. Geochim. Cosmochim. Acta 68, 547-556.

Wang, J., Chen, D., Yan, D., Wei, H., Xiang, L., 2012a. Evolution from an anoxic to oxic deep ocean during the Ediacaran-Cambrian transition and implications for bioradiation. Chem. Geol. 306, 129-138.

Wang, J., Li, Z.X., 2003. History of Neoproterozoic rift basins in South China: implications for Rodinia break-up. Precambrian Res. 122, 141-158.

Wang, X., Shi, X., Jiang, G., Zhang, W., 2012b. New U-Pb age from the basal Niutitang Formation in South China: implications for diachronous development and condensation of stratigraphic units across the Yangtze platform at the Ediacaran-Cambrian transition. J. Asian Earth Sci. 48, 1-8.

Wang, X., Shi, X., Tang, D., Zhang, W., 2013. Nitrogen isotope evidence for redox variations at the Ediacaran-Cambrian transition in South China. J. Geol. 121, 489-502.

Waser, N.A.D., Harrison, P.J., Nielsen, B., Calvert, S.E., Turpin, D.H., 1998. Nitrogen isotope fractionation during the uptake and assimilation of nitrate nitrite, ammonium, and urea by a marine diatom. Limnol. Oceanogr. 43, $215-224$

Weber, K.A., Achenbach, L.A., Coates, J.D., 2006a. Microorganisms pumping iron anaerobic microbial iron oxidation and reduction. Nat. Rev. Microbiol. 4 752-764.

Weber, K.A., Urrutia, M.M., Churchill, P.F., Kukkadapu, R.K., Roden, E.E., 2006b. Anaerobic redox cycling of iron by freshwater sediment microorganisms. Environ. Microbiol. 8, 100-113.

Wille, M., Nägler, T.F., Lehmann, B., Schröder, S., Kramers, J.D., 2008. Hydrogen sulphide release to surface waters at the Precambrian/Cambrian boundary. Nature 453, 767-769.

Xu, L.G., Lehmann, B., Mao, J.W., Nägler, T.F., Neubert, N., Böttcher, M.E., Escher, P., 2012. Mo isotope and trace element patterns of Lower Cambrian black shales in South China: multi-proxy constraints on the paleoenvironment. Chem. Geol. 318-319, 45-59.

Xu, L.G., Lehmann, B., Mao, J.W., Qu, W.J., Du, A.D., 2011. Re-Os age of polymetallic Ni-Mo-PGE-Au mineralization in early Cambrian black shales of South China a reassessment. Econ. Geol. 106, 511-522.

Yang, B., Steiner, M., Li, G., Keupp, H., 2014. Terreneuvian small shelly faunas of East Yunnan (South China) and their biostratigraphic implications. Palaeogeogr. Palaeoclimatol. Palaeoecol. 398, 28-58.

Zhang, W.-T., Hou, X.-G., 1985. Preliminary notes on the occurrence of the unusual trolobite Naraoia in Asia. Acta Palaeontol. Sin. 24, 591-599 (in Chinese with English abstract).

Zhou, C.-M., Zhang, J.-M., Li, G.-X., Yu, Z.-Y., 1997. Carbon and oxygen isotopic record of the Early Cambrian from the Xiaotan Section, Yunnan, south China. Sci. Geol. Sin. 32, 201-211 (in Chinese with English abstract).

Zhu, M.-Y., Babcock, L.E., Peng, S.-C., 2006. Advances in Cambrian stratigraphy and paleontology: integrating correlation techniques, paleobiology, taphonomy and paleoenvironmental reconstruction. Palaeoworld 15, 217-222.

Zhu, M., Zhang, J., Yang, A., 2007. Integrated Ediacaran (Sinian) chronostratigraphy of South China. Palaeogeogr. Palaeoclimatol. Palaeoecol. 254, 7-61.

Zhu, M., Zhang, J., Yang, A., Li, G., Steiner, M., Erdtmann, B.D., 2003. SinianCambrian stratigraphic framework for shallow- to deep-water environments of the Yangtze Platform: an integrated approach. Prog. Nat. Sci. 13, 951-960. 